
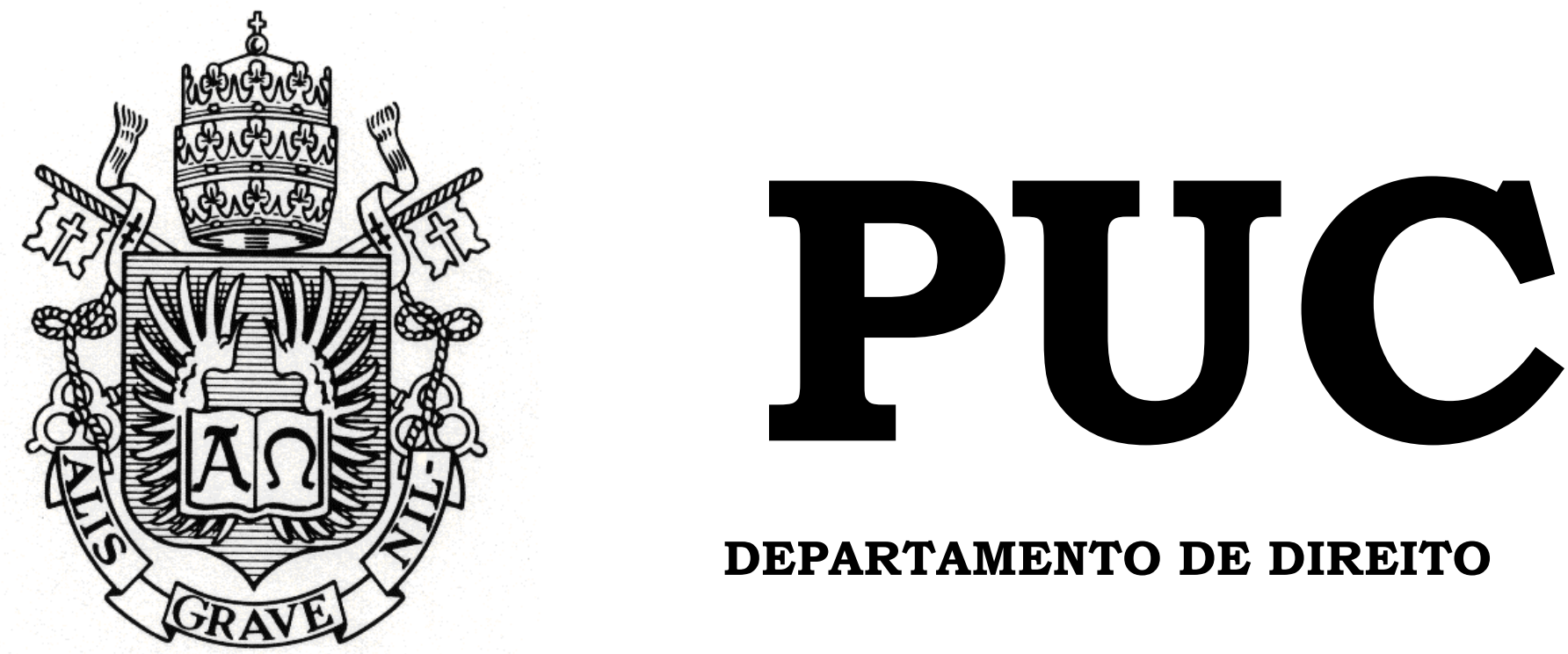

DEPARTAMENTO DE DIREITO

\title{
UNIÃO ESTÁVEL HOMOAFETIVA DE REFUGIADOS NO BRASIL
}

por

Carolina Sant' anna Dutra

ORIENTADORA: Thamis Dalsenter COORIENTADOR: Vitor Almeida

2018.2

PONTIFÍCIA UNIVERSIDADE CATÓLICA DO RIO DE JANEIRO

RUA MARQUÊS DE SÃO VICENTE, 225 - CEP 22453-900

RIO DE JANEIRO - BRASIL 


\section{UNIÃO ESTÁVEL HOMOAFETIVA DE REFUGIADOS NO BRASIL}

por

\section{CAROLINA SANT' ANNA DUTRA}

Monografia apresentada ao Departamento de Direito da Pontificia Universidade Católica do Rio de Janeiro (PUC-Rio) para a obtenção do título de Bacharel em Direito.

Orientadora: Thamis Dalsenter Coorientador: Vitor Almeida 


\section{AGRADECIMENTOS}

Agradeço, primeiramente, ao meu irmão Bernardo, que ainda no $2^{\circ}$ período da faculdade me ensinou o ressignificado da vida e foi meu chão para permanecer esses 5 anos longe de casa e ter chegado até o final.

Aos meus pais por todo o apoio, amizade e confiança construída ao longo desses anos.

Agradeço à PUC e ao Rio de Janeiro por ter me apresentado pessoas que engrandeceram essa jornada e estiveram ao meu lado: Ana Terra Quintaes, Ana Flávia Verri, Caroline de Cristo, Caroline Ramos, Florence Berrogain, Francisco Gradel, Isabella Figueiredo, Kally Regina Oliveira, Raquel Martins e Rayssa Fico. 


\section{RESUMO}

O presente trabalho monográfico visa investigar a possibilidade do reconhecimento de união estável homoafetiva de refugiados no Brasil para aqueles que não tinham o seu vínculo afetivo reconhecido pelo ordenamento jurídico do país de origem. Dessa forma, faz-se necessário o estudo sobre a evolução dos conceitos e o processo de reconhecimento de união estável no Brasil, bem como, os avanços acerca do reconhecimento da união estável homoafetiva no país. Para tanto, se examinará, mais a frente, status de "refugiado", tanto para efeitos nacionais, quanto internacionais. Com base em pesquisa empírica, pretende-se averiguar como seria o processo de refúgio para homossexuais que sofrem preconceito pela sua orientação sexual e procuram o reconhecimento da sua união estável com aquele que possui vínculo afetivo na sua terra natal.

Palavras-chave: União estável. União estável homoafetiva. Refúgio. Família. 


\section{SUMÁRIO}

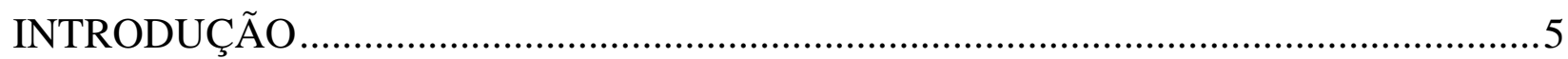

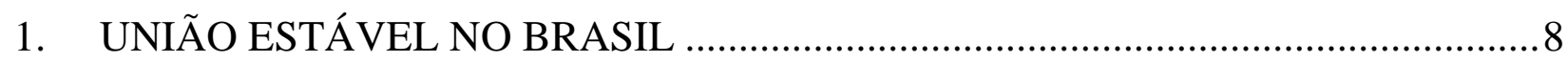

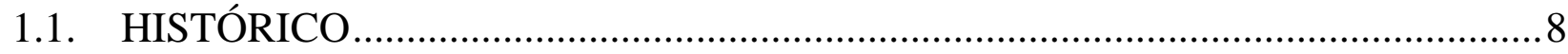

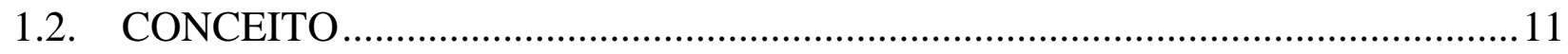

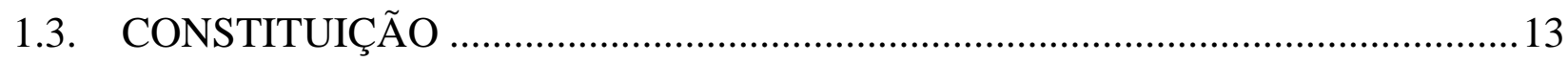

1.4. AÇÃO DE RECONHECIMENTO E DISSOLUÇÃO DE UNIÃO ESTÁVEL ......15

2. UNIÃO ESTÁVEL HOMOAFETIVA NO BRASIL .................................................. 17

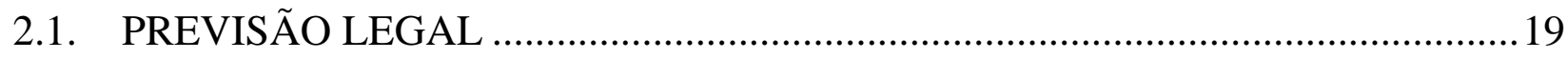

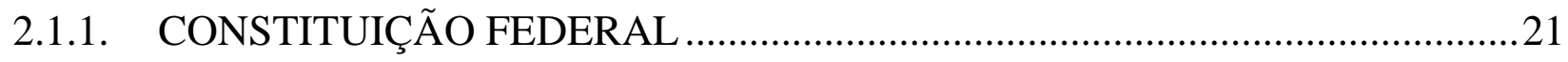

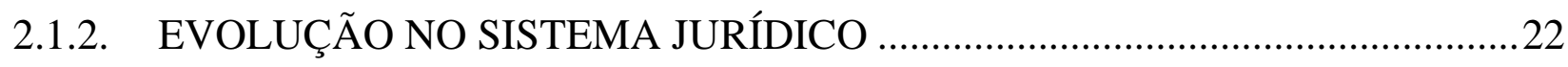

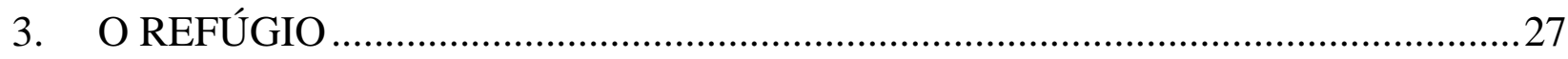

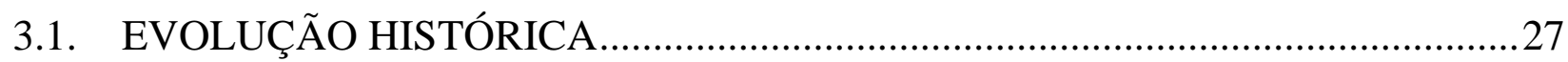

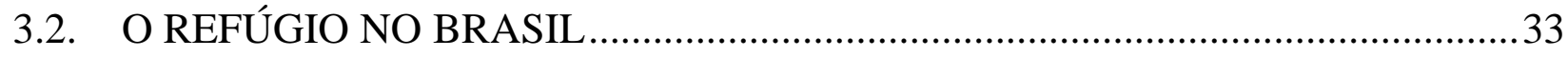

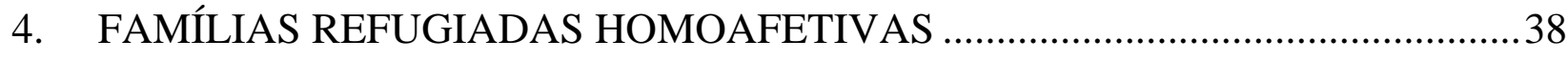

4.1. PERSPECTIVA BRASILEIRA PARA OS REFUGIADOS LGBTI ........................38

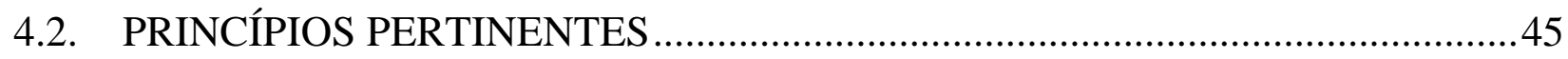

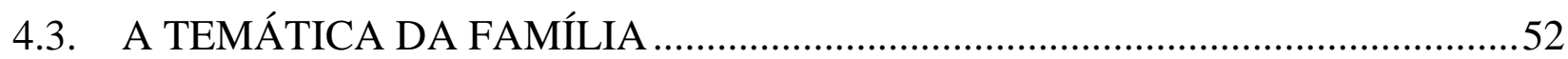

5. A ATUAÇÃO DA CRUZ VERMELHA NA REUNIFICAÇÃO FAMILIAR ..........55

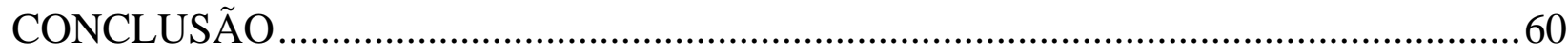

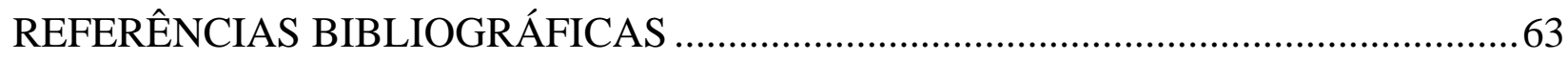




\section{INTRODUÇÃO}

Tendo em vista a crise humanitária vivenciada em alguns países africanos e do Oriente Médio, bem como em países latino-americanos vizinhos, o debate sobre refúgio retomou holofotes na mídia, nos órgãos internacionais e, por consequência, no ordenamento jurídico dos países que recebem os refugiados.

Para isso, será tratado, no capítulo 1, a evolução histórica, o conceito e a legislação referente à união estável homossexual. Já no capítulo 02, será abordada a união estável homoafetiva, com os seus impasses dentro da jurisprudência brasileira, a construção doutrinária sobre o tema e como foi o processo até chegar ao atual entendimento.

A homossexualidade é um fato social que está presente desde os primórdios na história da humanidade. Entretanto, com o surgimento das religiões e os ditames dos seus padrões de comportamento, criou-se uma cultura sobre pecado e referência aos homossexuais como algo pejorativo e defeituoso. A humanidade começou a enfrentar com preconceito a orientação sexual do próximo, apesar de a homossexualidade não ser uma opção, mas uma condição inerente à pessoa humana. Foi travada uma luta através de décadas para o reconhecimento da união estável como uma entidade familiar e, mais adiante, outra, para o reconhecimento da união estável entre pessoas do mesmo sexo.

O Supremo Tribunal Federal (STF), ao posicionar as uniões estáveis, tanto a heterossexual, quanto a homossexual, coloca, em prática, a disposição do princípio da igualdade, à medida que posiciona casais homossexuais e heterossexuais em isonomia no ordenamento jurídico, humanizando o conceito de família. 
O Brasil demorou a aceitar a realidade de que existiam uniões sólidas que não são constituídas através do casamento, atrasando o seu reflexo na legislação, até que não houve mais escapatória, pois foi percebido que não se podia limitar a identificação e constituição de casamento com apenas quatro artigos no Código Civil de 2002 tratando sobre as uniões estáveis, mas sim, definir família, para acompanhar as evoluções sociais, ligada a um vínculo fático e não apenas a um ato formal.

No capítulo 3 do presente trabalho monográfico, será apresentado o conceito de refúgio e refugiados, as condições para tal status, objetivo e procedimento do processo de refúgio no Brasil. Apesar do notório preconceito aos homossexuais em território nacional, legalmente, a perseguição aos mesmos é ilegal - fato que não se encontra como que não é a realidade de muitos países ao redor do mundo.

No capítulo 4 será apresentado o panorama internacional sobre a perspectiva dos refugiados ao virem para o Brasil, assim como a evolução do conceito de família e o princípio da unidade familiar construído para proteger os refugiados. E, ainda, no capítulo 5, será exposto a visita à Cruz Vermelha, em busca de um olhar do cotidiano e realista de profissionais que atuam na área.

Quando essas pessoas chegam com as vidas devastadas em uma terra completamente desconhecida e com fantasmas perversos, durante o processo de refúgio, é sabido que algumas destas não revelam o real motivo pelo qual sofreram perseguição, nem se sofreram perseguição. Por medo, muitos acusam outro motivo para conseguirem o status de refugiados, e não serem obrigados a retornarem à terra natal.

Resta evidente que uma das preocupações com o refugiado é que o mesmo possa seguir a própria vida, fortalecendo laços com aqueles que 
chegaram com eles, com os familiares que conseguiram permanecer juntos na travessia, e construindo novos laços no novo país. Portanto, um casal homossexual, ao chegar ao Brasil, não revela que sofreu perseguição no país de origem e que esse é o real motivo para ter decidido fugir daquela nação; e, ainda, aqueles que dizem que sofreram perseguição, em virtude de sua orientação sexual e de sua vivência com um companheiro, deverão ter apoio de esforços brasileiros para manter a união, reconhecendo-os um núcleo família. 


\section{UNIÃO ESTÁVEL NO BRASIL}

\subsection{HISTÓRICO}

Durante a história do Brasil, as relações não construídas pelo matrimônio não eram reguladas pelo ordenamento jurídico. No Código Civil de 1916, o reconhecimento se fazia, quando pleiteado, em uma ação de "indenização por serviços prestados" da mulher em face do homem, uma vez que a mulher exercia trabalho e dedicação ao lar, filhos e ao homem, não podendo ser diluída a relação de forma injusta à mulher ${ }^{1}$.

Posteriormente, a jurisprudência tornou a reconhecer tais relações através da ação de "sociedade de fato" - termo que comumente ainda é utilizado para demonstrar que, durante a relação, foram adquiridos bens através do esforço em pecúnia de cada um. Então, nessa modalidade, os companheiros eram tidos como "sócios", como os das empresas e, assim como em toda sociedade, sócios dividem lucros.

Porém, diante de uma separação, era necessário que cada parte comprovasse a sua contribuição financeira realizada para adquirir aquele bem, de modo a evitar o enriquecimento indevido. Fato é que a jurisprudência admitia a união estável apenas como uma sociedade de fato, entre sócios, na qual, podia-se indicar o direito de participação no patrimônio formado pelo esforço comum de ambos, e não como uma entidade familiar².

A Constituição Federal ampliou o conceito de família e reconheceu a união estável como entidade familiar, possuindo a mesma proteção legal do

\footnotetext{
${ }^{1}$ DIAS, Maria Berenice. Manual de direito das famílias. 12a ed. São Paulo: Editora Revista dos Tribunais, 2017, p. 253-254.

${ }^{2}$ GONÇALVES, Carlos Roberto. Direito Civil Brasileiro: Direito de Família. Volume 6. $14^{\mathrm{a}}$ ed. São Paulo: Saraiva, 2017, p. 804.
} 
casamento. O art. 226, $\S 3^{\circ}$, do referido diploma, dispõe: "Para efeito de proteção do Estado é reconhecida a união estável entre homem e mulher como entidade familiar, devendo a lei facilitar sua conversão em casamento"3.

\section{Caio Mário da Silva Pereira ${ }^{4}$ ensina:}

O princípio jurídico da afetividade, em que pese não estar positivado no texto constitucional, pode ser considerado um princípio jurídico, à medida que seu conceito é constituído por meio de uma interpretação sistemática da Constituição Federal (art. $5^{\circ}$, parágrafo $2^{\circ}, \mathrm{CF}$ ), princípio que é uma das grandes conquistas advindas da família contemporânea, receptáculo de reciprocidade de sentimentos e responsabilidades. Pode-se destacar um anseio social à formação de relações familiares afetuosas, em detrimento de preponderância, dos laços meramente sanguíneos e patrimoniais.

Logo, as uniões extraconjugais deixaram de ser apenas um fato social e se tornaram uma realidade jurídica com o advento da Constituição, colocando a união estável sob a proteção do Estado e caracterizando a entidade familiar ${ }^{5}$. Contudo, os processos continuaram tramitando nas varas cíveis, ou seja, ainda não eram vistos como de competência para as varas de família, com fulcro na súmula 380 do Supremo Tribunal Federal: "Comprovada a existência de sociedade de fato entre os concubinos, é cabível a sua dissolução judicial, com a partilha do patrimônio adquirido pelo esforço comum"6.

\footnotetext{
${ }^{3}$ BRASIL. Constituição da República Federativa do Brasil de 1988. Art. 226, §3. Da Família, da Criança, do Adolescente, do Jovem e do Idoso. Disponível em: <https://www.senado.leg.br/atividade/const/con1988/con1988_04.10.2017/art_226_.asp>. Acesso em 10 set. 2018.

${ }^{4}$ PEREIRA, Caio Mário da Silva. Instituições de Direito Civil: Direito de Família. Volume V. $18^{\mathrm{a}}$ ed. Rio de Janeiro: Editora Forense, 2010, p. 55-56.

${ }^{5}$ Ibid., p. 574.

${ }^{6}$ STF, RE 158.700, rel. min. Néri da Silveira, 2a T, Brasília, j. 30 out. 2001, DJ 22 fev. 2002.
} 
Nos Recursos Extraordinários $n^{\circ} 646721$ e $n^{\circ}$ 878694, o Supremo Tribunal Federal entendeu como inconstitucional o artigo $1.790^{7}$ do Código Civil $^{8}$, fazendo com que as uniões estáveis estivessem em igual direito de concorrência sucessória, atendendo ao princípio da igualdade, isto é, concedendo, de fato, às uniões estáveis, os mesmos direitos do casamento e mesmo direito para fins sucessórios, não existindo qualquer hierarquia entre eles. $\mathrm{O}$ (a) companheiro(a) que, antes, só podia ter direito sobre aqueles bens adquiridos durante a união, agora será herdeiro necessário, tendo direito a quarta parte da herança ${ }^{9}$.

A lei $n^{\circ} 8.971 / 1994$ tratou pela primeira vez sobre união estável e estabeleceu como o homem e a mulher solteiros, separados judicialmente, divorciados ou viúvos, que comprovassem a união por mais de cinco anos ou tenham filhos. Além disso, instituiu o conceito de "esforço comum", a fim de deixar os companheiros livres para decidirem acerca da proporção dos esforços de cada um em direção à constituição de seu patrimônio, em caso de dissolução da união estável. ${ }^{10} J a ́$ a lei no 9.278/96, não elegeu tempo mínimo de convivência ou a existência de filho, apenas levou em consideração a convivência duradoura, pública e contínua de um homem e de uma mulher que quisessem constituir família. Aqui, surgiram as expressões "conviventes" e "companheiros"; também renovou o entendimento quanto ao "esforço comum", passando a presumir que o patrimônio construído pelo casal é fruto

\footnotetext{
${ }^{7}$ Art. 1.790. A companheira ou o companheiro participará da sucessão do outro, quanto aos bens adquiridos onerosamente na vigência da união estável, nas condições seguintes: I - se concorrer com filhos comuns, terá direito a uma quota equivalente à que por lei for atribuída ao filho; II - se concorrer com descendentes só do autor da herança, tocar-lhe-á a metade do que couber a cada um daqueles; III se concorrer com outros parentes sucessíveis, terá direito a um terço da herança; IV - não havendo parentes sucessíveis, terá direito à totalidade da herança.

${ }^{8}$ BRASIL. Código Civil. Lei n. 10.406, de 10 jan. 2002. Institui o Código Civil. Disponível em: <http://www.planalto.gov.br/ccivil_03/leis/2002/110406.htm>. Acesso em 10 set. 2018.

${ }^{9}$ Art. 1.832. Em concorrência com os descendentes (art. 1.829, inciso I) caberá ao cônjuge quinhão igual ao dos que sucederem por cabeça, não podendo a sua quota ser inferior à quarta parte da herança, se for ascendente dos herdeiros com que concorrer.

${ }^{10}$ PEREIRA, Caio Mário da Silva. Instituições de Direito Civil: Direito de Família. Volume V. $18^{\mathrm{a}}$ ed. Rio de Janeiro: Editora Forense, 2010, p. 575-581.
} 
do esforço de ambos, de igual maneira, não sendo necessária a comprovação de maior ou menor contribuição ${ }^{11}$.

As leis de 1994 e 1996 supramencionadas foram revogadas, uma vez que o assunto foi abordado no Código Civil de 2002, o qual passou a ter um Livro de Direito de Família e incorporou cinco artigos (do artigo 1.723 ao 1.727) dispondo sobre união estável ${ }^{12}$.

Ademais, fixou-se a competência para as varas de família e consagrouse o direito real de habitação. Os bens passaram a ser entendidos como fruto de um esforço comum. Então, conforme artigo 1.723 do Código Civil ${ }^{13}$ :

É reconhecida como entidade familiar a união estável entre o homem e a mulher, configurada na convivência pública, contínua e duradoura e estabelecida com o objetivo de constituição de família.

Como Zeno Veloso ${ }^{14}$ discorre:

Essa entidade familiar decorre desse fato, da aparência de casamento, e a essa aparência é o elemento objetivo da relação, a mostra, o sinal exterior, a fachada, o fator de demonstração inequívoca da constituição de uma família.

\subsection{CONCEITO}

A união estável é um fato jurídico que nasce da convivência a partir do momento em que duas pessoas decidem, em suma, formar uma entidade

\footnotetext{
${ }^{11}$ GONÇALVES, Carlos Roberto. Direito Civil Brasileiro: Direito de Família. Volume 6. $14^{\mathrm{a}}$ ed. São Paulo: Saraiva, 2017, p. 793-794.

${ }^{12}$ Ibid., p. 795.

${ }^{13}$ BRASIL. Código Civil. Lei n. 10.406, de 10 jan. 2002. Institui o Código Civil. Disponível em: <http://www.planalto.gov.br/ccivil_03/leis/2002/110406.htm>. Acesso em 10 set. 2018.

${ }^{14}$ VELOSO, 2002, p. 115, apud GONÇALVES, 2017, p. 800.
} 
familiar, em virtude da sua relação, composta por um homem e uma mulher, os quais possuem vida em comum estável e aparentemente permanente, constituindo uma vida familiar e usufruindo do mesmo patrimônio ${ }^{15}$.

A consolidação da união estável vem, portanto, da própria convivência, afeto, compromisso, comprometimento, ainda que não determinado pelo Estado. A lei apenas exige notoriedade da união, devendo ser uma relação pública, inexistindo prazo temporal mínimo; assim, será comprovada a existência do relacionamento ${ }^{16}$.

Presente no artigo 1.724 do Código Civil de 2002, as relações entre os companheiros obedecerão aos deveres de lealdade, respeito e assistência, e de guarda, sustento e educação dos filhos. O doutrinador Carlos Roberto Gonçalves ${ }^{17}$ ressalta que, quando esse artigo menciona o dever de respeito, refere-se aos direitos da personalidade dos companheiros na forma de liberdade, honra, intimidade e dignidade. Por isso, na união estável, o casal deve ser livre para construir a sua família com dignidade, uma vez que preserva a sua honra e possui intimidade.

Vale ressaltar que, para a declaração da união estável, não é obrigatória a vida sob mesmo teto. Por vezes, o casal, pela profissão, circunstância familiar ou pessoal, acaba cedendo ao distanciamento físico, porém, preserva ainda a convivência, a posse do estado de casado, mútua assistência, vida social em comum, isto é, apesar da distância, permanece o ânimo de constituir família, não se consegue negar a existência da entidade familiar ${ }^{18}$. $\mathrm{O}$ afeto deve

\footnotetext{
${ }^{15}$ PEREIRA, Caio Mário da Silva. Instituições de Direito Civil: Direito de Família. Volume V. $18^{\mathrm{a}}$ ed. Rio de Janeiro: Editora Forense, 2010, p. 574.

${ }^{16}$ BENJÓ, Daniel. Os novos tipos de família: um estudo sobre a união homoafetiva. Rio de Janeiro, 2013. 62 f. Monografia (Monografia em Direito) - Pontifícia Universidade Católica (PUC).

${ }^{17}$ GONÇALVES, Carlos Roberto. Direito Civil Brasileiro: Direito de Família. Volume 6. 14ª ed. São Paulo: Saraiva, 2017, p. 816.

${ }^{18}$ Ibid., p. 801.
} 
ser o ponto distintivo preponderante para o conceito de família e marco para a constituição e declaração da união estável por parte do Estado.

\subsection{CONSTITUIÇÃO}

O casal em união estável, portanto, é aquele que vive como tal perante os amigos, a família e a sociedade, com a fama de esposa e a fama de marido. O tempo de duração não é elemento fundamental para a caracterização da união estável, tampouco, a inclusão do sobrenome do companheiro ao nome da companheira ou a coabitação, como já dito. Certo é que as uniões devem se revelar duradouras, com ânimo de serem relações matrimoniais, com participação de esforços e fidelidade ${ }^{19}$.

É sabida a possibilidade de os companheiros firmarem um contrato de convivência na união estável e, por consequência, o seu regime de bens ${ }^{20}$. Assim, ainda na lei 9.278/1996, e no Código Civil de 2002, no artigo $1.725^{21}$, é esclarecido que o casal pode celebrar um contrato escrito que afaste a comunhão parcial de bens, fazendo com que a união estável seja regida pela comunhão universal ou separação absoluta, por exemplo, ou ainda, pode administrar os seus bens, visto que não é prevista a necessidade do contrato ser celebrado no início exato da união, podendo as partes celebrarem durante a união estável, colocando ou não efeitos retroativos ${ }^{22}$.

\footnotetext{
${ }^{19}$ PEREIRA, Caio Mário da Silva. Instituições de Direito Civil: Direito de Família. Volume V. $18^{\mathrm{a}}$ ed. Rio de Janeiro: Editora Forense, 2010, p.578-583.

${ }^{20}$ DIAS, Maria Berenice. Manual de direito das famílias. 12a ed. São Paulo: Editora Revista dos Tribunais, 2017, p. 267.

${ }^{21}$ Art. 1.725. Na união estável, salvo contrato escrito entre os companheiros, aplica-se às relações patrimoniais, no que couber, o regime da comunhão parcial de bens.

${ }^{22}$ GONÇALVES, Carlos Roberto. Direito Civil Brasileiro: Direito de Família. Volume 6. 14a ed. São Paulo: Saraiva, 2017, p. 831.
} 
Francisco José Cahali ${ }^{23}$ expressa que:

\begin{abstract}
Não reclama forma preestabelecida ou já determinada para sua eficácia, embora se tenha como necessário seja escrito, e não apenas verbal. Assim, poderá revestir-se da roupagem de uma convenção solene, escritura de declaração, instrumento contratual particular levado ou não a registro em Cartório de Títulos e Documentos, documento informal, pacto e, até mesmo, ser apresentado apenas como disposições ou estipulações esparsas, instrumentalizadas em conjunto ou separadamente, desde que contenham a manifestação bilateral da vontade dos companheiros.
\end{abstract}

Vale ressaltar que não é exigível o contrato escrito, formalizado, para a constituição da união estável.

Atualmente, pelo Código Civil de 2002, no artigo 1.725, está implícito que o que vale é a solidariedade que uniu o casal durante um tempo, não sendo prudente avaliar a contribuição financeira de cada um. Restando provada a união estável, é presumida a colaboração de ambos conviventes para a aquisição do bem ${ }^{24}$. Assim, em hipótese de dissolução da união, os bens deverão ser partilhados pela metade.

Pode haver, na dissolução da união e no que tange aos bens patrimoniais, quando houver consenso e registrado no título de propriedade que o adquirente convivia em união estável, partilha extrajudicial ou por contrato particular ${ }^{25}$. Se não transigirem, a demanda deverá ser encaminhada ao poder judiciário, podendo ser pleiteada a desconsideração da personalidade

${ }^{23}$ CAHALI, Francisco José. Contrato de Convivência na União Estável. São Paulo: Saraiva, 2002, p. 55-56.

${ }^{24}$ VIEIRA, Cláudia Nascimento. A união estável no novo código civil. In: EMERJ. Curso 10 anos do código civil: aplicação, acertos, desacertos, e novos rumos. Rio de Janeiro: Divisão de Publicações da EMERJ, 2013, p. 77.

${ }^{25}$ DIAS, Maria Berenice. Manual de direito das famílias. 12a ed. São Paulo: Editora Revista dos Tribunais, 2017, p. 281. 
da pessoa jurídica de uma sociedade, quando uma das partes tiver necessidade para esclarecer a existência de um determinado bem ${ }^{26}$.

\subsection{AÇÃO DE RECONHECIMENTO E DISSOLUÇÃO DE UNIÃO ESTÁVEL}

A união estável precisa ser algo público e contínuo, com o objetivo de constituir família. Não precisa, necessariamente, do Estado para configuração, bastando o seu animus para a constituição de família. Ao ingressar com uma ação de reconhecimento de união estável, essa ação nada mais é que uma ação declaratória de união estável. Logo, possui natureza declaratória e não constitutiva do Estado, como o casamento. O mesmo ocorre com a dissolução. O juiz declara uma união que está previamente diluída, pois já ocorreu o fim da convivência. Se houver fundamento, a parte pode requerer a separação de corpos, tutelada no artigo 1.562 do Código Civil, para resguardar a integridade física dos envolvidos e para selar a incomunicabilidade entre eles, a fim de que um deles saia de casa, colocando fim à relação ${ }^{27}$.

É preciso lembrar que a constituição de união estável pode ser realizada através de escritura pública, justificação judicial ou ação declaratória, não existindo para dissolução fator decisivo como a culpa. A competência para tramitação das ações é das varas de família, conforme a lei 9.278/1996, sob segredo de justiça, de acordo disciplinado no Código de Processo Civil ${ }^{28}$. A pessoa casada, porém separada de fato, pode manter união estável, caso não

\footnotetext{
${ }^{26}$ Ibid., p. 282.

${ }^{27}$ Ibid., p. 284.

${ }^{28}$ Art. 189. Os atos processuais são públicos, todavia tramitam em segredo de justiça os processos: III

- em que constem dados protegidos pelo direito constitucional à intimidade.
} 
esteja impedida pelo artigo, 1.521, §1, do Código Civil de 2002, excluído o inciso $\mathrm{VI}^{29}$.

Da mesma forma, nas ações post mortem, o companheiro é legitimado como herdeiro para figurar na ação. Conforme ensina Maria Berenice Dias ${ }^{30}$,

[...] só é concedida pensão por morte ao companheiro sobrevivente: (a) se o óbito ocorreu após 24 meses de contribuição e (b) se a união teve início há mais de dois anos antes do óbito. A pensão passou a corresponder a $50 \%$ do benefício e só é vitalícia se o beneficiário tiver 35 anos de expectativa de vida. Atualmente, se tiver 44 anos ou mais. Abaixo desta idade há todo um cálculo diferenciado, sendo que, se o sobrevivente tiver menos de 21 anos, receberá pensão por apenas três anos (L 13.135/15).

Se, da união, advierem filhos menores ou incapazes, não é possível optar pela via extrajudicial, ou seja, por escritura pública para fins de dissolução. Na ação de dissolução deverão ser estabelecidos critérios para convivência dos filhos com ambos os pais, bem como, alimentação e visitação. Se a ação for consensual, a petição inicial deve ser assinada por ambos, mesmo quando não advieram filhos da união. É dispensada, mesmo havendo incapazes, a audiência de conciliação, sendo apenas obrigatória a promoção do Ministério Público ${ }^{31}$.

Em virtude da obrigação de mútua assistência entre os companheiros, especialmente nos momentos difíceis, o princípio da solidariedade aplica-se no âmbito do patrimônio no que tange a obrigação alimentar ${ }^{32}$.

\footnotetext{
${ }^{29}$ PEREIRA, Caio Mário da Silva. Instituições de Direito Civil: Direito de Família. Volume V. $18^{\mathrm{a}}$ ed. Rio de Janeiro: Editora Forense, 2010, p. 796.

${ }^{30}$ DIAS, Maria Berenice. Manual de direito das famílias. 12a ed. São Paulo: Editora Revista dos Tribunais, 2017, p. 280.

${ }^{31}$ Ibid., p. 279-280.

${ }^{32}$ GONÇALVES, Carlos Roberto. Direito Civil Brasileiro: Direito de Família. Volume 6. 14ª ed. São Paulo: Saraiva, 2017, p. 816.
} 


\section{UNIÃO ESTÁVEL HOMOAFETIVA NO BRASIL}

É de conhecimento público mundial o histórico preconceito da humanidade com os homossexuais, não só no cotidiano, mas também na restrição de direitos praticada pelo poder judiciário. O Estado é aquele que deveria tratar todos como iguais, independentemente da escolha íntima e representativa que optaram para suas vidas, atendendo aos fins sociais e às exigências do bem comum. Pode-se afirmar que uma parcela de seres humanos ainda tem direitos sociais e individuais limitados, uma vez que é vítima de um repúdio social, o qual prejudica o decorrer da vida de um ser humano que deseja viver de forma digna, sem rótulos pejorativos e discriminatórios.

Diante do problema social, não podia ser diferente no direito, que também tem como função regular os problemas provenientes da sociedade, dando soluções a elas, à medida que não deve privar alguém de um direito previsto para outros, tampouco, fingir que determinada problemática é inexistente, seja ela tão grave como a discriminação.

A premissa é a ideia de que os homossexuais devem ser tratados com o mesmo respeito e consideração que os cidadãos e, que a recusa estatal ao reconhecimento das uniões, implica não só em privá-los de uma série de direitos importantíssimos de conteúdo patrimonial e extrapatrimonial, como também importa em menosprezo à sua própria identidade e dignidade ${ }^{33}$.

A homossexualidade sempre existiu e continuará existindo. Nunca foi crime no Brasil ou contagioso, o que não justifica a exclusão social proposta a esse grupo, nem mesmo o argumento de infertilidade, pois se não podem gerar

\footnotetext{
${ }^{33}$ STF, ADI n. 4277, Rel. Ministro Ayres Britto, Brasília, 05 mai. 2011.
} 
filhos biológicos, não podem constituir família; entretanto, filhos não são requisitos para o reconhecimento da entidade familiar. E ainda, casais homossexuais podem ser pais através de reprodução assistida, conforme Resolução do Conselho Federal de Medicina, resolução de 2017 e CF n ${ }^{\circ}$ $2.121 / 15^{34}$, e a adoção, pois filhos para serem legítimos não precisam do fator biológico.

Portanto, é preciso que tribunais brasileiros não possuam caráter discriminatório e prezem pela igualdade entre as uniões heterossexuais e uniões homoafetivas, sem deixar as últimas à margem jurídica. Vale lembrar que, mesmo com a lacuna legislativa sobre o reconhecimento das uniões homoafetivas, tais como entidades familiares, contraria princípios vigentes da Constituição Federal ${ }^{35}$.

Apesar da marginalização das uniões estáveis, a ausência de lei não pode justificar a inexistência do direito. Diante de uma demanda com tal problemática, as uniões homoafetivas merecem reconhecimento ${ }^{36}$, pois não há impedimento no ordenamento jurídico brasileiro para a orientação afetiva humana. Dito isso, não pode existir discriminação daqueles que escolhem pela homossexualidade. Diogo de Calazans Melo de Andrade $^{37}$, integrante da Comissão de Combate ao Preconceito e à Discriminação da OAB de Sergipe, apoia que a Constituição:

\footnotetext{
${ }^{34}$ DIAS, Maria Berenice. Manual de direito das famílias. 12a ed. São Paulo: Editora Revista dos Tribunais, 2017, p. 287.

${ }^{35}$ LIMA, Marcellus Polastri; TRANCOSO, Renata Vitória Oliveira dos S. União homoafetiva: contornos da decisão em ação declaratória de inconstitucionalidade de conversão do reconhecimento da união homoafetiva em casamento. In: Direito de família [Recurso eletrônico on-line]. Org. CONPEDI/ UNICURITIBA. Coord.: SANTIAGO, Mariana Ribeiro; SILVA, Marcos Alves da; CARDIM, Valéria Silva Galdino. Florianópolis: FUNJAB, 2013, p. 217.

${ }^{36}$ DIAS, Maria Berenice. Op. Cit., p. 286.

${ }^{37}$ ANDRADE, 2005, p. 59, apud LIMA; TRANCOSO, s. d., p. 4.
} 
[...] não é taxativo[a], não apresenta proibição expressa para a constituição das relações entre pessoas do mesmo sexo e deve ser interpretado[a] com auxílio do método da 'unidade da constituição' pelo qual o operador do direito deve integrar todas as normas constitucionais.

Dessa forma, entendendo que é preciso suprir a lacuna legislativa com os preceitos da Constituição, ressalta Maria Berenice Dias ${ }^{38}$ sobre as formas de família:

Foi o afeto e o princípio da afetividade que trazem legitimidade a todas as formas de família. Portanto, hoje, todas as relações e formações de família são legítimas. Com a consagração do afeto como direito fundamental, não há como deixar de reconhecer que as uniões afetivas entre pessoas do mesmo sexo também são marcadas pelo elo da afetividade.

As uniões homoafetivas nada mais são que uniões de pessoas do mesmo sexo que, ao manterem uma relação ininterrupta, com respeito recíproco, afeto e uma comunhão de vida, desejam ser reconhecidas como uma entidade familiar, uma vez que também possuem o requisito de vida comum, respeito, afeto, solidariedade e assistência, por exemplo.

\subsection{PREVISÃO LEGAL}

Como o reconhecimento da união estável foi garantido exclusivamente aos casais heterossexuais, o judiciário primeiramente reconheceu a indenização por serviços prestados às uniões homoafetivas, depois, às "sociedades de fato",

\footnotetext{
${ }^{38}$ DIAS, Maria Berenice. União homoafetiva: o preconceito e a justiça. $5^{\text {a }}$ ed. Rio de Janeiro: Editora Revista dos Tribunas, 2012, p. 93.
} 
dispostas no artigo $981^{39}$, do Código Civil. Claramente eram as uniões estáveis vistas apenas como uma relação negocial e não como uma família, excluindoas, mais uma vez, do direito de família e, por consequência, do direito sucessório e previdenciário ${ }^{40}$.

Todavia, não subsiste qualquer argumento razoável para negar aos homossexuais o direito ao pleno reconhecimento das relações afetivas estáveis que mantêm, com todas as consequências jurídicas disso decorrentes. $\mathrm{O}$ reconhecimento da união entre pessoas do mesmo sexo independe de qualquer mediação legislativa, em razão da possibilidade de aplicação imediata dos princípios constitucionais ${ }^{41}$.

Entidade familiar é toda e qualquer espécie de união capaz de servir de acolhedouro das afeições humanas ${ }^{42}$, conforme disposto no artigo 226 da Constituição Federal ${ }^{43}$, o qual reconheceu as relações afetivas que não sejam oriundas do casamento, não podendo ser diferenciadas por origem, raça, sexo ou idade. A Constituição Federal deve, portanto, assegurar e proteger as famílias e as pessoas, independentemente de sua orientação sexual. Não faz sentido a exclusão dessas famílias, pois elas atendem aos critérios básicos de relação duradoura, pública e contínua ${ }^{44}$.

O Código Civil de 2002 incluiu Livro IV de Direito de Família, porém não foi claro quanto às uniões homoafetivas, devendo essa lacuna ser suprida

\footnotetext{
39 BRASIL. Código Civil. Lei n. 10.406, de 10 jan. 2002. Institui o Código Civil. Disponível em: <http://www.planalto.gov.br/ccivil_03/leis/2002/110406.htm>. Acesso em 10 set. 2018.

40 DIAS, Maria Berenice. Manual de direito das famílias. 12 $2^{\mathrm{a}}$ ed. São Paulo: Editora Revista dos Tribunais, 2017, p. 289.

${ }^{41}$ STF, ADI n. 4277, Rel. Ministro Ayres Britto, Brasília, 05 mai. 2011

${ }^{42}$ WIKIPÉDIA. Entidade familiar. Disponível em: 〈https://pt.wikipedia.org/wiki/Entidade_familiar〉. Acesso em 15 set. 2018.

${ }^{43}$ BRASIL. Constituição da República Federativa do Brasil de 1988. Art. 226, §3º. Da Família, da Criança, do Adolescente, do Jovem e do Idoso. Disponível em: <https://www.senado.leg.br/atividade/const/con1988/con1988_04.10.2017/art_226_.asp>. Acesso em 10 set. 2018.

44 DIAS, Maria Berenice. Manual de direito das famílias. 12a ed. São Paulo: Editora Revista dos Tribunais, 2017, p. 286-287.
} 
pelas outras fontes do direito. Na ação civil pública $\mathrm{n}^{\circ} 2000.71 .00 .009347-0^{45}$, na Vara Previdenciária de Porto Alegre, por exemplo, foi deferida uma medida liminar para o Instituto Nacional do Seguro Social (INSS), o qual editou uma instrução normativa $n^{\circ} 25$, nos anos 2000, para conceder o benefício ao companheiro homossexual, com eficácia erga omnes. E, também, a $3^{\text {a }}$ Turma do Superior Tribunal de Justiça, no RESP $\mathrm{n}^{\circ}$ 23.871/RS, em 2006, foi favorável à inscrição do parceiro em plano de saúde ${ }^{46}$.

\subsubsection{CONSTITUIÇÃO FEDERAL}

Não é possível a exclusão da entidade familiar das uniões homoafetivas pelo artigo 226 da Constituição Federal, de acordo com Paulo Diniz Lôbo ${ }^{47}$, pois os tipos de entidades familiares dispostos no referido artigo são meramente exemplificativos. As outras entidades familiares estão implícitas no conceito de família descrito no caput: "Art. 226. A família, base da sociedade, tem especial proteção do Estado"48.

Além disso, o artigo $1^{\circ}$, inciso $3^{\circ}$, da Constituição Federal, institui que cabe à República Federativa do Brasil constituir um Estado Democrático de Direito, sendo um dos fundamentos a dignidade da pessoa humana. Ora, não é possível construir um Estado Democrático de Direito quando não se protege ou se deixa à margem do direito um determinado grupo da sociedade.

\footnotetext{
${ }^{4}$ VARA PREVIDENCIÁRIA DE PORTO ALEGRE, Apelação Cível n. 2000.71.00.009347-0/RS, Rel. Des. Federal João Batista Pinto Silveira, Porto Alegre, 29 jul. 2005.

${ }^{46}$ PEREIRA, Caio Mário da Silva. Instituições de Direito Civil: Direito de Família. Volume V. $18^{\mathrm{a}}$ ed. Rio de Janeiro: Editora Forense, 2010, p. 584.

${ }^{47}$ LÔBO, Paulo Luiz Netto. Entidades familiares constitucionalizadas: para além do numerus clausus. In: Revista Brasileira de Direito de Família. Porto Alegre: Síntese, n. 12, jan./mar. 2002, p. 48.

48 LIMA, Marcellus Polastri; TRANCOSO, Renata Vitória Oliveira dos S. União homoafetiva: contornos da decisão em ação declaratória de inconstitucionalidade de conversão do reconhecimento da união homoafetiva em casamento. In: Direito de família [Recurso eletrônico on-line]. Org. CONPEDI/ UNICURITIBA. Coord.: SANTIAGO, Mariana Ribeiro; SILVA, Marcos Alves da; CARDIM, Valéria Silva Galdino. Florianópolis: FUNJAB, 2013, p. 221.
} 
O princípio da igualdade e liberdade para a escolha da construção da entidade familiar deve atender a conveniência afetiva. Não pode o legislador deixar como ilegítimo algo que provoca prejuízo ao cidadão. Lôbo ${ }^{49}$ afirma:

[...] não podem ser protegidas algumas entidades familiares e desprotegidas outras, pois a exclusão refletiria nas pessoas que as integram por opção ou por circunstâncias da vida, comprometendo a realização do princípio da dignidade humana.

O princípio da igualdade, resguardado no artigo $5^{\circ}$ da Constituição Federal, de forma evidente, prevê que todas as entidades familiares devem ter o mesmo tratamento, por isso, garante o direito de escolha do parceiro $\operatorname{afetivo~}^{50}$.

\subsubsection{EVOLUÇÃO NO SISTEMA JURÍDICO}

Em 2001, no Rio Grande do Sul, foi decidida a competência para as varas de família em relação às demandas sobre união estável homoafetiva, assim como o reconhecimento da mesma como entidade familiar ${ }^{51}$. Perante o precedente, os demais tribunais passaram a se declararem a favor da união ${ }^{52}$. Veja-se:

É de ser reconhecida judicialmente a união homoafetiva mantida entre duas mulheres de forma pública e ininterrupta pelo período de 16 anos. A homossexualidade é um fato social que se perpetua através dos séculos, não mais podendo o Judiciário se olvidar de

\footnotetext{
${ }^{49}$ LÔBO, Paulo Luiz Netto. Op. Cit., p. 49.

${ }^{50}$ LIMA, Marcellus Polastri; TRANCOSO, Renata Vitória Oliveira dos S. Op. Cit., p. 223-224.

${ }^{51}$ COMARCA DE PORTO ALEGRE, Apelação Cível n. 70012836755, Rel. Desa. Maria Berenice Dias, Porto Alegre, 21 dez. 2005.

52 DIAS, Maria Berenice. Manual de direito das famílias. 12ª ed. São Paulo: Editora Revista dos Tribunais, 2017, p. 289.
} 
emprestar a tutela jurisdicional a uniões que, enlaçadas pelo afeto, assumem feição de família. A união pelo amor é que caracteriza a entidade familiar e não apenas a diversidade de sexos. É o afeto a mais pura exteriorização do ser e do viver, de forma que a marginalização das relações homoafetivas constitui afronta aos direitos humanos por ser forma de privação do direito à vida, violando os princípios da dignidade da pessoa humana e da igualdade $^{53}$.

Em 2004, o Tribunal Superior Eleitoral ${ }^{54}$ tornou inelegível o(a) parceiro(a) de união homossexual para reprimir a manutenção de um mesmo grupo no poder, atendendo ao artigo 14, §7, da Constituição Federal, in verbis ${ }^{55}$ :

Art. 14,\$7. São inelegíveis, no território de jurisdição do titular, o cônjuge e os parentes consangüíneos ou afins, até o segundo grau ou por adoção, do Presidente da República, de Governador de Estado ou Território, do Distrito Federal, de Prefeito ou de quem os haja substituído dentro dos seis meses anteriores ao pleito, salvo se titular de mandato eletivo e candidato à reeleição.

Em 2005, também no Tribunal de Justiça do Rio Grande do Sul, foi acolhido o reconhecimento da união estável homoafetiva, sob o fundamento da ausência da lei específica sobre o tema, não implicando ausência de direito, pois existem mecanismos para suprir as lacunas legais, aplicando-se aos casos concretos analogia, os costumes e os princípios gerais do direito, em consonância com os preceitos constitucionais (art. 4, DA LINDB) ${ }^{56}$.

\footnotetext{
${ }^{53}$ COMARCA DE PORTO ALEGRE, Op. Cit.

${ }^{54}$ TSE, Recurso Especial Eleitoral n. 24.564/PA, Rel. Ministro Gilmar Mendes, Brasília, 02 out. 2004.

${ }^{55}$ LIMA, Marcellus Polastri; TRANCOSO, Renata Vitória Oliveira dos S. Op. Cit., p. 226

${ }^{56}$ GONÇALVES, Carlos Roberto. Direito Civil Brasileiro: Direito de Família. Volume 6. 14a ed. São Paulo: Saraiva, 2017, p. 805.
} 
AÇÃO DECLARATÓRIA. RECONHECIMENTO. UNIÃO ESTTÁVEL. CASAL HOMOSSEXUAL. PREENCHIMENTO DOS REQUISITOS. CABIMENTO. A ação declaratória é o instrumento jurídico adequado para reconhecimento da existência de união estável entre parceria homoerótica, desde que afirmados e provados os pressupostos próprios daquela entidade familiar. A sociedade moderna, mercê da evolução dos costumes e apanágio das decisões judiciais, sintoniza com a intenção dos casais homoafetivos em abandonar os nichos da segregação e repúdio, em busca da normalização de seu estado e igualdade às parelhas matrimoniadas ${ }^{57}$. EMBARGOS INFRINGENTES ACOLHIDOS, POR MAIORIA. (SEGREDO DE JUSTIÇA) (Embargos Infringentes $N^{\circ}$ 70011120573, Quarto Grupo de Câmaras Cíveis, Tribunal de Justiça do RS, Relator: José Carlos Teixeira Giorgis, Julgado em 10/06/2005) (TJ-RS - EI: 70011120573 RS, Relator: José Carlos Teixeira Giorgis, Data de Julgamento: 10/06/2005, Quarto Grupo de Câmaras Cíveis, Data de Publicação: Diário da Justiça do dia 18/11/2005)

Em 2006, no Superior Tribunal de Justiça, o ministro Humberto Gomes de Barros foi relator do Recurso Especial no 238.715 - RS, e usou a analogia com a união estável heterossexual como fundamento, pois, na omissão da lei, pelo artigo $4^{\circ}$, da Lei de Introdução ao Código Civil, o juiz deve usar a analogia. Tão logo, para votar no seguinte sentido:

No caso em análise, estão preenchidos os requisitos exigidos pela lei para a percepção do benefício pretendido: vida em comum, laços afetivos, divisão de despesas. Ademais, não há que alegar a ausência de previsão legislativa, pois antes mesmo de serem regulamentadas as relações concubinárias já eram concedidos alguns direitos à companheira, nas relações heterossexuais. Trata-se da evolução do Direito, que, passo a passo, valorizou a afetividade humana abrandando os preconceitos e as formalidades sociais legais ${ }^{58}$.

\footnotetext{
${ }^{57}$ TJRS, EI n. 70011120573, Rel. José Carlos Teixeira Giorgis, Rio Grande do Sul, 18 nov. 2005.

58 LIMA, Marcellus Polastri; TRANCOSO, Renata Vitória Oliveira dos S. União homoafetiva: contornos da decisão em ação declaratória de inconstitucionalidade de conversão do reconhecimento da união homoafetiva em casamento. In: Direito de família [Recurso eletrônico on-line]. Org. CONPEDI/ UNICURITIBA. Coord.: SANTIAGO, Mariana Ribeiro; SILVA, Marcos Alves da; CARDIM, Valéria Silva Galdino. Florianópolis: FUNJAB, 2013, p. 226.
} 
Em 2009, foi proposta a Arguição de Preceito Fundamental perante o Supremo Tribunal Federal, $\mathrm{n}^{\circ}$ 4277/DF, com fundamento na não discriminação, na lacuna legislativa e na analogia, a qual teve acórdão baseado nos princípios da igualdade, liberdade, dignidade da pessoa humana; também no princípio da segurança jurídica, pois não se pode ter incerteza quanto às consequências jurídicas da união homoafetiva dentro da sociedade, e no princípio da razoabilidade, já que não havia mais justificativas para a não proteção $^{59}$.

Após os avanços jurisprudenciais, o Supremo Tribunal Federal, em 05 de maio de 2011, enfim reconheceu as uniões homoafetivas como entidades familiares, garantindo o status de unidade familiar. Ao julgar a Ação Direta de Inconstitucionalidade $\mathrm{n}^{\circ} 4.277$ e a arguição de descumprimento de preceito fundamental $\mathrm{n}^{\circ}$ 132, proposta pelo então Governador do Estado do Rio de Janeiro, Sérgio Cabral, o Supremo Tribunal Federal, reconheceu a união estável para casais do mesmo sexo. O relator, ministro Ayres Britto, votou no sentido de dar interpretação conforme a Constituição Federal para excluir qualquer significado do artigo 1.723 do Código Civil que impeça o reconhecimento da união entre pessoas do mesmo sexo como entidade familiar. O ministro também argumentou no sentido de que artigo $3^{\circ}$, inciso IV, da Constituição Federal, veda qualquer discriminação em virtude de sexo, raça, cor e que, nesse sentido, ninguém pode ser diminuído ou discriminado em função de sua preferência sexual ${ }^{60}$.

Em virtude da referida decisão do STF, o Conselho Nacional de Justiça elaborou o provimento 37/2014, autorizando o registro das uniões estáveis

\footnotetext{
${ }^{59}$ Ibid., p. 224.

${ }^{60}$ PORTAL DE NOTÍCIAS DO SUPREMO TRIBUNAL FEDERAL. Supremo reconhece união homoafetiva. <http://www.stf.jus.br/portal/cms/verNoticiaDetalhe.asp?idConteudo=178931>. Acesso em 20 set. 2018.
} 
entre pessoas do mesmo sexo ${ }^{61}$. A proteção constitucional de família, portanto, não deve se limitar com as uniões estáveis ou casamentos heterossexuais, como se houvesse a possibilidade de estabelecer um rol taxativo de família padrão, não considerando as práticas e inovações sociais.

Os dispositivos legais (artigo 226, parágrafo $3^{\circ}$ e artigo 1.723 do Código Civil) não podem ser interpretados para um determinado grupo da sociedade. Quis o legislador colocar de forma literal para não estender os efeitos do direito àqueles que não se encaixam na forma convencional da sociedade, ou seja, sujeitando-se a uma interpretação preconceituosa de diferenciação.

${ }^{61}$ DIAS, Maria Berenice. Manual de direito das famílias. 12 $2^{\mathrm{a}}$ ed. São Paulo: Editora Revista dos Tribunais, 2017, p. 291. 


\section{O REFÚGIO}

\subsection{EVOLUÇÃO HISTÓRICA}

O marco inicial da história sobre refúgio é o fim da Primeira Guerra Mundial e o Império Otomano com a Revolução Russa. Nesse período, aproximadamente 1,5 milhão de pessoas se deslocaram em busca de refúgio. Dessa forma, pela primeira vez, a comunidade internacional se viu obrigada a organizar assentamentos, repatriações, e a elaborar operações de socorro e proteção $^{62}$.

Com a Segunda Guerra Mundial, os deslocamentos em busca de refúgio tomaram proporções jamais vistas. Para tanto, com o avanço nazista, em 1943, foi criada a Administração de Socorro e Reabilitação para gerir essa situação. Com isso, foi necessário estabelecer um conceito de quem é a pessoa refugiada. Tal conceituação foi estipulada na Conferência de Bermudas (1943), restringindo essa definição exclusivamente para aqueles acontecimentos ocorridos na Europa, ou seja, excluindo os acontecimentos nos outros países. É certo, contudo, que violações de direitos humanos, assim como o terror, são cometidas em todo o planeta ${ }^{63}$.

Todas as pessoas que de qualquer procedência que, como resultado de acontecimentos na Europa, tiveram que abandonar seus países de residência por terem em perigo suas vidas ou liberdade, devido a sua raça, religião ou crenças políticas ${ }^{64}$.

\footnotetext{
${ }^{62}$ BARRETO, Luiz Paulo Teles Ferreira. A Lei Brasileira de Refúgio: sua história. In: BARRETO, Luiz Paulo Teles Ferreira (Org.). Refúgio no Brasil: a proteção brasileira aos refugiados e seu impacto nas Américas. Brasília: ACNUR, Ministério da Justiça, 2010, p. 14.

${ }^{63}$ Ibid., p. 14.

${ }^{64}$ Definição para refugiado na Conferência de Bermudas de 1943.
} 
Continuando a jornada, a Assembleia Geral das Nações Unidas, em 1946, consagrou o princípio non-refoulement, em que não se pode obrigar o regresso do refugiado ao país do qual fugiu, caso ele tenha uma razão concreta para permanecer no país onde se encontra. Em contrapartida, quando a situação política e/ou de perseguição for cessada, deve-se estimular o retorno do refugiado ao seu país. Em 1947, surgiu a Organização Internacional do Refugiado (OIR) para dirimir os últimos problemas dos refugiados no final da Segunda Guerra ${ }^{65}$.

Posteriormente a esse período, em 1950, foi criado o Alto Comissariado das Nações Unidas (ACNUR) para os Refugiados, através de uma resolução das Organizações das Nações Unidas (ONU), inicialmente com um mandato de apenas três anos, exatamente para reassentar os refugiados da Segunda Guerra Mundial. Somente em 1974, o ACNUR foi nominado para a proteção e assistência dos apátridas no mundo todo. Desde 2003, o ACNUR não precisa mais renovar o seu mandato ${ }^{66}$.

Na Convenção sobre o Estatuto dos Refugiados (Convenção de 1951), o refugiado foi definido como:

Toda pessoa que, como resultado de acontecimentos ocorridos antes de $1^{\circ}$ de janeiro de 1951 e devido a fundados temores de ser perseguida por motivo de raça, religião, nacionalidade, por pertencer a determinado grupo social e por suas opiniões políticas, se encontre fora do país de sua nacionalidade e não possa, ou por causa dos ditos temores não queira recorrer à proteção de tal país; ou que, carecendo de nacionalidade e estando, em consequência de tais acontecimentos, fora do país onde tivera sua residência

\footnotetext{
${ }^{65}$ BARRETO, Luiz Paulo Teles Ferreira. A Lei Brasileira de Refúgio: sua história. In: BARRETO, Luiz Paulo Teles Ferreira (Org.). Refúgio no Brasil: a proteção brasileira aos refugiados e seu impacto nas Américas. Brasília: ACNUR, Ministério da Justiça, 2010, p. 14 e 15.

${ }^{66}$ ALTO COMISSARIADO DAS NAÇÕES UNIDAS PARA OS REFUGIADOS. Protegendo os refugiados no Brasil e no Mundo. Brasília: ACNUR, 2014, p. 5.
} 
habitual, não possa ou por temor fundado não queira regressar a $\mathrm{ele}^{67}$.

Esse conceito também era aplicado apenas para os acontecimentos ocorridos na Europa. Além disso, houve a restrição temporal do ano de 1951, excluindo os acontecimentos posteriores a esse ano. Por isso, ainda havia a necessidade de ampliar o conceito, a fim da efetivação dos direitos da pessoa humana.

Em 1960, o Brasil aderiu à Convenção de 1951, mas o ACNUR instalou-se na América Central, 10 anos depois, em 1970, para observar e auxiliar a América Latina, em conjunto com a Igreja Católica, em virtude das ditaduras que assolaram tal região. As Cáritas, portanto, prestavam assistência as pessoas que cruzavam a fronteira para o Brasil, mesmo sabendo que, se descobertas naquelas condições de governo, podiam ser obrigadas a retornarem ${ }^{68}$.

Já no final da ditadura brasileira, em 1984, a Declaração de Cartagena recomendou que os países incorporassem o conceito de refugiado ao seu ordenamento jurídico, ampliando o conceito para todos que tivessem fugido pela preservação de sua vida, segurança e liberdade, ou por violência generalizada, conflito interno, violação de direitos humanos ou perturbação grave da ordem pública ${ }^{69}$, sendo refugiado aquele que:

Entende-se também como refugiado as pessoas que tenham saído de seus países porque sua vida, segurança ou liberdade tenham sido ameaçadas pela violência generalizada, agressão estrangeira, conflitos internos, violação massiva de direitos humanos ou outras

\footnotetext{
${ }^{67}$ BARRETO, Luiz Paulo Teles Ferreira. Op. Cit., p. 15.

${ }^{68}$ Ibid., p. 17.

${ }^{69}$ Ibid., p. 16.
} 
circunstâncias que tenham perturbado gravemente a ordem pública $^{70}$.

Sendo assim, o ACNUR ocupa-se para que, qualquer pessoa que precise, tenha o direito de buscar refúgio e, caso queira, retorne ao país de origem. Então, o ACNUR só trabalha para proteger os refugiados. É um desafio encontrar outras formas eficientes para as migrações econômicas e deslocamentos forçados com a segurança das fronteiras ${ }^{71}$.

O órgão busca soluções duradouras para os refugiados, sendo uma delas a integração local, para que o refugiado se insira socialmente, assim como haja inserção econômica e cultural, fato que deve ser realizado com respeito aos seus direitos e acesso às políticas públicas. Até mesmo o reassentamento é efetuado, caso tenha problemas com a integração local ou falta de proteção legal ou física. Nesse último caso, o ACNUR procura ajuda de outros países para receberem esse refugiado ${ }^{72}$.

A Lei no 9.474/1997 trouxe para o cenário nacional a definição do termo refugiado, tendo em vista o conceito pré-estabelecido pela ONU, em conjunto com a Declaração de Cartagena. Vale ressaltar que um dos direitos previstos é o direito à reunião familiar, isto é, estende-se a concessão de refúgio para os outros membros da família daquele que obteve a concessão. Essa regra também vigora no Estatuto do Refugiado de 1951.

Art. $2^{\circ}$ Os efeitos da condição dos refugiados serão extensivos ao cônjuge, aos ascendentes e descendentes, assim como aos demais

\footnotetext{
${ }^{70}$ Definição estabelecida na Declaração de Cartagena em 1984.

71 ALTO COMISSARIADO DAS NAÇÕES UNIDAS PARA OS REFUGIADOS. Protegendo os refugiados no Brasil e no Mundo. Brasília: ACNUR, 2014, p. 6 e 8.

${ }^{72}$ Ibid., p. 14.
} 
membros do grupo familiar que do refugiado dependerem economicamente, desde que se encontrem em território nacional ${ }^{73}$.

Além disso, essa lei possui as chamadas "soluções duráveis" para os refugiados, enfatizando o aspecto voluntário de repatriamento, reassentamento e integração local.

Art. 42. A repatriação de refugiados aos seus países de origem deve ser caracterizada pelo caráter voluntário do retorno, salvo nos casos em que não possam recusar a proteção do país de que são nacionais, por não mais subsistirem as circunstâncias que determinaram o refúgio ${ }^{74}$.

Contudo, a lei só trata de documentação e educação, sem analisar a necessidade de passos práticos, como e onde o Brasil ajudará o refugiado com atendimento psicológico, por exemplo, em virtude do trauma que sofreu; como terá acesso aos programas sociais e culturais; onde procurará trabalho; se terá direitos políticos; qual será a sua condição de vida. Os acessos para essas informações caminham a pequenos passos ${ }^{75}$.

No Brasil, o artigo $1^{\circ}$ da Lei $9.474 / 1997^{76}$ define refugiado como:

Art. $1^{\circ}$ Será reconhecido como refugiado todo indivíduo que:

I - devido a fundados temores de perseguição por motivos de raça, religião, nacionalidade, grupo social ou opiniões políticas encontre-

\footnotetext{
${ }^{73}$ BRASIL. Código Civil. Lei n. 9.474, de 22 jul. 1997. Define mecanismos para a implementação do Estatuto dos Refugiados de 1951, e determina outras providências. Disponível em: <http://www.planalto.gov.br/ccivil_03/leis/19474.htm>. Acesso em 25 set. 2018.

${ }^{74}$ Ibid.

${ }^{75}$ MOREIRA, Julia Bertino. Refugiados no Brasil: reflexões acerca do processo de integração local. In: Revista Interdisciplinar da Mobilidade Humana. Brasília, Ano XXII, n. 43, jul./dez. 2014, p. 93.

${ }^{76}$ BRASIL. Código Civil. Lei n. 9.474, de 22 jul. 1997. Define mecanismos para a implementação do Estatuto dos Refugiados de 1951, e determina outras providências. Disponível em: <http://www.planalto.gov.br/ccivil_03/leis/19474.htm〉. Acesso em 25 set. 2018.
} 
se fora de seu país de nacionalidade e não possa ou não queira acolher-se à proteção de tal país;

II - não tendo nacionalidade e estando fora do país onde antes teve sua residência habitual, não possa ou não queira regressar a ele, em função das circunstâncias descritas no inciso anterior;

III - devido a grave e generalizada violação de direitos humanos, é obrigado a deixar seu país de nacionalidade para buscar refúgio em outro país.

Essa lei institui o Estatuto do Refugiado no Brasil. Foi elaborada pelo ACNUR e pela sociedade civil, a qual é considerada pela ONU uma das leis mais abrangentes e modernas. Ela inclui os dispositivos de proteção internacional, cria um órgão específico para o atendimento dos refugiados, o Comitê Nacional para os Refugiados (CONARE), com sede em Brasília. O referido órgão rege as políticas públicas e decide quanto às solicitações de refúgio. Além disso, estipula os direitos e as obrigações do solicitante de refúgio e refugiado, além da assistência administrativa, sendo a primeira a tratar sobre deslocamento forçado de refugiado ${ }^{77}$.

Apesar da recente Lei $\mathrm{n}^{\mathrm{o}} 13.445$, de 2017, foi definido no artigo 121 da nova Lei de Migração que "Na aplicação desta Lei, devem ser observadas as disposições da Lei $\mathrm{n}^{\circ}$ 9.474, de 22 de julho de 1997, nas situações que envolvam refugiados e solicitantes de refúgio"78. Em síntese, não há colisão entre os diplomas normativos, que devem ser aplicados de forma coordenada.

Essa lei, nos seus artigos $1^{\circ}$ e $3^{\circ}$, conceitua grave e generalizada violação de direitos humanos, assim como é considerada pelo CONARE, sendo a total incapacidade de ação ou ausência de um Estado Democrático de

\footnotetext{
${ }^{77}$ BARRETO, Luiz Paulo Teles Ferreira (Org.). Refúgio no Brasil: a proteção brasileira aos refugiados e seu impacto nas Américas. Brasília: ACNUR, Ministério da Justiça, 2010, p. 19 e 51.

${ }^{78}$ BRASIL. Código Civil. Lei n. 13.445, de 24 mai. 2017. Institui a Lei de Migração. Disponível em: <http://www.planalto.gov.br/ccivil_03/_Ato2015-2018/2017/Lei/L13445.htm>. Acesso em 25 set. 2018.
} 
Direito, quando não se identifica a existência de um Estado que o protege e ao qual possa recorrer; ausência de paz estável e durável; reconhecimento da comunidade internacional de que aquele território está em situação de grave e generalizada violação de direitos humanos ${ }^{79}$.

Essas pessoas comuns deixaram suas vidas para trás, sua família, seus amigos, seus empregos foram abandonados, porque tais indivíduos precisavam preservar a sua liberdade, segurança e vida. Vale ressaltar que também são refugiados aqueles que tiveram de deixar o seu país, em razão de violência generalizada, conflitos armados e/ou violação massiva de direitos humanos ${ }^{80}$.

\subsection{O REFÚGIO NO BRASIL}

Apesar da atuação do Estado e do ACNUR, a sociedade civil e as instituições religiosas foram fundamentais na história da relação do Brasil com a recepção dos estrangeiros para a integração social com os membros da comunidade local, sob aspecto da assistência jurídica e social ${ }^{81}$.

Antes da decisão final sobre o reconhecimento do refúgio, levando em consideração que o processo pode ser demorado, o estrangeiro, além de possuir direito ao trabalho, ele e os membros da sua família possuem permissão de residência provisória no Brasil e devem receber documentos provisórios de identidade, após a propositura do pedido de refúgio. Para auxiliar nessa demanda, foi criado o CONARE, formado pelos representantes dos Ministérios da Justiça, Relações Exteriores, Trabalho, Saúde, Educação, Departamento da Polícia Federal e da sociedade civil (como as Cáritas, por exemplo), todos com

\footnotetext{
${ }^{79}$ MOREIRA, Julia Bertino. Refugiados no Brasil: reflexões acerca do processo de integração local. In: Revista Interdisciplinar da Mobilidade Humana. Brasília, Ano XXII, n. 43, jul./dez. 2014, p. 89.

${ }^{80}$ ALTO COMISSARIADO DAS NAÇÕES UNIDAS PARA OS REFUGIADOS. Protegendo os refugiados no Brasil e no Mundo. Brasília: ACNUR, 2014, p. 4.

${ }^{81}$ MOREIRA, Julia Bertino. Op. Cit., p. 93.
} 
direito a voz e voto nas suas deliberações. O ACNUR também presencia as deliberações, porém, somente com direito a voz ${ }^{82}$.

Dentre as contribuições do CONARE estão: julgar em primeira instância os pedidos de refúgio; determinar perda e cessação da condição de refugiado; orientar e coordenar ações necessárias à eficácia da proteção, assistência e apoio jurídico aos refugiados ${ }^{83}$. A solicitação de refúgio pode ser ex officio ou a requerimento das autoridades competentes e, ainda, declarar a perda da condição de refugiado, coordenar ações para proteção, assistência e integração local e apoio jurídico com a participação dos referidos Ministérios $^{84}$.

Ademais, o refugiado também possui direito à saúde, devendo ser atendido em hospitais públicos, uma vez que o ACNUR repassa verba para esses locais; também podem ingressar nas universidades públicas; alimentação e moradia são garantidas pela rede de apoio em parceira com instituições privadas. É sabido que as Organizações Não Governamentais (ONGs) e algumas instituições também oferecem auxílio para alimentação, curso de idiomas e cursos profissionalizantes. E o ACNUR financia o auxílio prestado pelas Cáritas, assim como a preparação técnica para o trabalho ${ }^{85}$.

O Alto Comissariado das Nações Unidas para Refugiados, portanto, possui parceria com as autoridades estaduais, municipais e a sociedade civil, que são fundamentais para atender às necessidades dessa população, atuando como verdadeiros interlocutores. No Brasil, formaram-se alguns comitês para

\footnotetext{
${ }^{82}$ Comitê Nacional para os Refugiados.

${ }^{83}$ MOREIRA, Julia Bertino. Refugiados no Brasil: reflexões acerca do processo de integração local. In: Revista Interdisciplinar da Mobilidade Humana. Brasília, Ano XXII, n. 43, jul./dez. 2014, p. 92.

${ }^{84}$ AHLERT, Mara; ALMEIDA, Alcione de. A inclusão social das pessoas na condição de refugiado no Brasil à luz dos direitos humanos. In: Revista Barbarói. Santa Cruz do Sul, Edição Especial n. 47, jan./jun. 2016, p. 15.

${ }^{85}$ BARRETO, Luiz Paulo Teles Ferreira. A Lei Brasileira de Refúgio: sua história. In: BARRETO, Luiz Paulo Teles Ferreira (Org.). Refúgio no Brasil: a proteção brasileira aos refugiados e seu impacto nas Américas. Brasília: ACNUR, Ministério da Justiça, 2010, p. 14.
} 
ajudar essas pessoas, como no Rio de Janeiro, em São Paulo, no Rio Grande do Sul e no Paraná, por exemplo. Nesses locais, as autoridades e o comitê dialogam sobre soluções viáveis e práticas para atender os refugiados ${ }^{86}$. As Cátedras também foram incorporadas por inúmeras universidades, tais como a Universidade do Estado do Rio de Janeiro, a Universidade Federal do Rio de Janeiro, a Universidade Federal do Estado do Rio de Janeiro, a Universidade Federal Fluminense e a Pontifícia Universidade Católica do Rio de Janeiro, além das Cáritas Arquiodiocesanas no Rio de Janeiro e em São Paulo, por exemplo ${ }^{87}$.

As Redes de Proteção Solidária são compostas por pessoas e organizações pela causa dos refugiados. Nessas redes, há o monitoramento das fronteiras, inclusão social dos refugiados, integração local e reassentamento solidário $^{88}$.

Os refugiados e estrangeiros residentes no Brasil possuem os mesmos direitos, tais como liberdade de pensamento, deslocamento, propriedade, não sujeição à tortura e a tratamento degradante, assistência médica, direito ao trabalho e à educação. Contudo, devem cumprir a lei brasileira e respeitar os costumes nacionais. Se a situação do refugiado for emergencial, o refugiado pode receber do ACNUR ajuda financeira e material ${ }^{89}$.

Todavia, mesmo parecendo ser um processo simples em um país acolhedor, o refugiado pode ter dificuldade, principalmente, para aprender o português e com a adaptação cultural. O português pode ser um idioma muito complicado de ser aprendido para algumas nacionalidades. É notório que o Brasil ainda é deficiente nos grandes centros de um ambiente internacional

\footnotetext{
${ }^{86}$ ALTO COMISSARIADO DAS NAÇÕES UNIDAS PARA OS REFUGIADOS. Protegendo os refugiados no Brasil e no Mundo. Brasília: ACNUR, 2014, p. 19.

${ }^{87}$ Ibid., p. 16.

${ }^{88}$ Ibid., p. 18.

${ }^{89}$ Ibid., p. 7.
} 
bilíngue, trilíngue, que possa apoiar as pessoas que precisarem, assim como,- $\Theta$ também é carente para acesso ao setor da saúde e carente no acesso ao mercado de trabalho, educação e serviços públicos ${ }^{90}$. Acaba sendo, na maioria das vezes, os programas da sociedade civil que realizam esse atendimento ${ }^{91}$.

Logo, diante do compromisso jurídico e político que o Brasil declarou, o país vem sendo visto como um lugar de acolhimento, apesar das lacunas de eficiência, quanto ao amparo, assistência jurídica e social, acesso à saúde, educação e trabalho. Essa visão deve-se ao fato da diversidade étnica e miscigenação cultural do país, sem guerras, entendendo-se que aqui há uma convivência pacífica de todas as culturas. Isso porque a demanda para atender aos refugiados depende de políticas públicas, orçamento do Estado, ações internas e sociedade civil organizada - o que é difícil pensar no atual cenário político e econômico do Brasil. Entretanto, as instituições, como ACNUR, CONARE e Cáritas, mantêm os esforços em seus trabalhos ${ }^{92}$.

O Brasil reconhece e ratifica convenções internacionais sobre refugiados, mas ainda não tem a efetivação dos direitos desses indivíduos ao ingressarem no país com qualidade de vida. As pessoas acabam sendo atendidas por ONGs ou Cáritas de cunho de defesa de direitos humanos e atuação social na área. Contudo, a Constituição Federal no artigo $1^{\circ}$, consagra o princípio da dignidade da pessoa humana. Isto é, abrange a igualdade de forma digna entre as pessoas, impossibilitando a redução das condições de vida do ser humano para um nível que cause a degradação ou submissão para extrema miséria ou exploração. Dessa forma, impõe ao ordenamento jurídico brasileiro que resguarde as pessoas de viverem em condições indignas. No que tange aos direitos dos refugiados, presume-se que o indivíduo voltará a ter

\footnotetext{
90 ALTO COMISSARIADO DAS NAÇÕES UNIDAS PARA OS REFUGIADOS. Protegendo os refugiados no Brasil e no Mundo. Brasília: ACNUR, 2014, p. 16.

${ }^{91}$ MOREIRA, Julia Bertino. Refugiados no Brasil: reflexões acerca do processo de integração local. In: Revista Interdisciplinar da Mobilidade Humana. Brasília, Ano XXII, n. 43, jul./dez. 2014, p. 142.

${ }^{92}$ Ibid., p. 135, 141 e 142.
} 
condições mínimas de existência, liberdade e dignidade para iniciar uma nova vida, sem qualquer perseguição ${ }^{93}$.

Assim, como ponto de partida, o estrangeiro deve ter acesso ao mercado de trabalho e à educação. Certo é, na prática, que eles são incluídos nesses direitos supramencionados, mas excluídos de participação política, o que implica na representação política dentro da nova sociedade, fincando à margem de que algum representante abrace a sua causa. Presume-se que essas pessoas serão incluídas em programas ou políticas sociais de integração no país receptor e nas suas legislações ${ }^{94}$.

Nessa logística, é necessário esforço do governo nacional e da comunidade nacional, a fim de propiciar oportunidades de emprego para que ocorra a integração social. Logo, garante-se a fixação dos direitos do estrangeiro, ao passo que, também é preciso atentar para direitos básicos, como já mencionado, o direito à moradia, saúde, cidadania, ainda que idioma e cultura sejam um obstáculo ${ }^{95}$.

A integração social, portanto, é um processo fundamental, no qual procura-se manter a identidade dos refugiados, apesar de fazerem parte de uma nova sociedade, uma vez que o refugiado passa a conviver com os nativos de outro país, ajustando os seus comportamentos, devendo ser preservado a $\begin{array}{llll}\text { cultura } & \text { originária } & \text { do } & \text { estrangeiro } \\ & 96\end{array}$

\footnotetext{
${ }^{93}$ AHLERT, Mara; ALMEIDA, Alcione de. A inclusão social das pessoas na condição de refugiado no Brasil à luz dos direitos humanos. In: Revista Barbarói, Santa Cruz do Sul, Edição Especial n. 47, jan./jun. 2016, p. 18.

${ }_{94}$ MOREIRA, Julia Bertino. Refugiados no Brasil: reflexões acerca do processo de integração local. In: Revista Interdisciplinar da Mobilidade Humana. Brasília, Ano XXII, n. 43, jul./dez. 2014, p. 90.

${ }^{95}$ Ibid., p. 88 e 89.

${ }^{96}$ Ibid., p. 88 e 89.
} 


\section{FAMÍLIAS REFUGIADAS HOMOAFETIVAS}

\subsection{PERSPECTIVA BRASILEIRA PARA OS REFUGIADOS LGBTI}

O Brasil é visto internacionalmente como um país acolhedor também em relação à sexualidade e ao gênero para pedidos de refúgio LGBTI, já que partem do pressuposto de que aqui é "legal" até mesmo o casamento entre pessoas do mesmo sexo ${ }^{97}$. Em 2002, o Brasil teve o primeiro caso de refúgio fundado na orientação sexual. Dois homens colombianos mantinham um relacionamento e eram perseguidos por grupos armados colombianos da região que executavam homossexuais e pediram refúgio no Brasil.

Contudo, Paris, Nova York e Berlim continuam com a reputação de um "mundo gay”, ou que é possível ser gay com liberdade, isto é, um lugar onde possam realizar suas aspirações, tornar possível o que é impossível no seu país ${ }^{98}$. O "mundo ocidental" é caracterizado, teoricamente, pelo respeito à diversidade sexual e de gênero, com igualdade ${ }^{99}$.

Desde 2002, o Brasil concede refúgio motivado pela orientação sexual do solicitante, seguindo os passos da Alemanha, Argentina, Bélgica, Canadá, Dinamarca, Espanha, Estados Unidos, Holanda, Reino Unido e Suécia ${ }^{100}$. Cabe ressaltar que

97 FRANÇA, Isadora Lins. "Refugiados LGBTI": direitos e narrativas entrecruzando gênero, sexualidade e violência. In: Cadernos Pagu [online]. Dossiê Conservadorismo, Direitos, Moralidades e Violência, São Paulo, n. ${ }^{\circ}$ 50, 2017, p. 5.

98 ANDRADE, Vitor Lopes. Refugiados e refugiadas por orientação sexual no Brasil: dimensões jurídicas e sociais. In: Seminário "Migrações Internacionais, Refúgio e Politicas". São Paulo, 2016, p. 3.

${ }^{99}$ FRANÇA, Isadora Lins. Op. Cit., p. 3.

${ }^{100}$ ANDRADE, Op. Cit., p. 2, 5. 
O ACNUR estima que 37 Estados já concederam refúgio a indivíduos cujo fundado temor de perseguição relacionava-se à orientação sexual e/ou identidade de gênero. Contudo, ainda há muitos Estados que não o fizeram e cujas práticas e procedimentos estão aquém dos padrões internacionais. O Brasil já processou mais de 250 solicitações cujo fundamento da perseguição diz respeito a questões relacionadas a sexo, orientação sexual e/ou identidade de gênero. Além de reconhecer solicitações dessa natureza, o Brasil tem realizado esforços para garantir que pessoas LGBTI tenham acesso a um procedimento de determinação da condição de refugiado sensível às necessidades de proteção específicas dessa população ${ }^{101}$.

O ACNUR, em 2008, publicou o UNHCR Guidance note on refugee daims relating to sexual orientation and gender identity, incluindo a orientação sexual e a identidade de gênero, para adequação à lei. Passaram a permanecer a classe de "grupo social" para o pedido de refúgio com fundado temor de perseguição. Desse modo, os LGBTI ${ }^{102}$ se tornaram um grupo social específico que justifica a solicitação de refúgio, quando tem sistematicamente seus direitos violados e são potenciais vítimas dessas violações ${ }^{103}$. Eles consagram os princípios de Yogyakarta, no qual o homossexual possui direito à solicitação de refúgio, uma vez que pode ser vítima de perseguição. Todavia, o guia tem caráter de recomendação; devem, portanto, os Estados, procederem para elaborarem as próprias legislações sobre o tema ${ }^{104}$.

Vale ressaltar que "perseguição" é considerada quando existem graves violações de direitos humanos com ameaça à vida e à liberdade, assim como violência física, psicológica e sexual, que são comuns aos homossexuais. E

${ }^{101}$ ACNUR. Cartilha Informativa sobre a Proteção de Pessoas Refugiadas e Solicitantes de Refúgio LGBTI. Disponível em: <http://www.acnur.org/portugues/wp-content/uploads/2018/02/Cartilhainformativa-sobre-a-prote $\% \mathrm{C} 3 \% \mathrm{~A} 7 \% \mathrm{C} 3 \% \mathrm{~A} 3 \mathrm{o}$-de-pessoas-refugiadas-e-solicitantes-deref\%C3\%BAgio-LGBTI_ACNUR-2017.pdf>. Acesso em 6 out. 2018.

${ }^{102}$ Lésbicas, gays, bissexuais, trans e intersexos.

103 FRANÇA, Isadora Lins. "Refugiados LGBTI": direitos e narrativas entrecruzando gênero, sexualidade e violência. In: Cadernos Pagu [online]. Dossiê Conservadorismo, Direitos, Moralidades e Violência, São Paulo, n. ${ }^{\circ}$ 50, 2017, p. 11.

104 ANDRADE, Vitor Lopes. Refugiados e refugiadas por orientação sexual no Brasil: dimensões jurídicas e sociais. In: Seminário "Migrações Internacionais, Refúgio e Políticas". São Paulo, 2016, p. 4-5. 
também que o estupro é a principal forma de violação de dignidade dessas pessoas, usada como forma de tortura ${ }^{105}$.

A Constituição Federal de 1988 possui três artigos fundamentais, para essa análise, que consagram o princípio da dignidade da pessoa humana, o princípio da igualdade e os direitos sociais, sendo eles os artigos $1^{\circ}, 5^{\circ}$ e $6^{\circ 106}$.

Nessa linha, foi elaborada a Resolução $\mathrm{n}^{\circ} 11$, de 18 de dezembro de 2014, do Conselho Nacional de Combate à Discriminação e Promoção dos Direitos de Lésbicas, Gays, Bissexuais, Travestis e Transsexuais, para proteger as questões relacionadas à orientação sexual e identidade de gênero. Depois, o mesmo conselho editou a Resolução no 12 e no 13, em 2015, para que esse grupo tivesse controle de práticas discriminatórias ${ }^{107}$.

Apesar dos atos normativos citados, ocorre tentativa de destruição desse grupo e, por isso, fazem jus ao pedido de refúgio. $\mathrm{O}$ art. $1^{\circ}$ da Convenção de 1951 e a lei brasileira não são explícitos quanto ao refúgio especificamente para a comunidade LGBTI, mas sim, há uma recomendação para que os Estados adotem a solicitação como pertencentes a um grupo social. Isso, na prática, pode levar à rejeição do pedido de refúgio no CONARE, pois a entrevista é revestida de subjetividade quando o fundamento é a orientação

105 FRANÇA, Isadora Lins. Op. Cit., p. 11.

106 Art. $1^{\text {o }}$ A República Federativa do Brasil, formada pela união indissolúvel dos Estados e Municípios e do Distrito Federal, constitui-se em Estado Democrático de Direito e tem como fundamentos: [...] III - a dignidade da pessoa humana; [...]

Art. $5^{\circ}$ Todos são iguais perante a lei, sem distinção de qualquer natureza, garantindo-se aos brasileiros e aos estrangeiros residentes no País a inviolabilidade do direito à vida, à liberdade, à igualdade, à segurança e à propriedade, nos termos seguintes: [...] III - ninguém será submetido a tortura nem a tratamento desumano ou degradante; [... X X - são invioláveis a intimidade, a vida privada, a honra e a imagem das pessoas, assegurado o direito a indenização pelo dano material ou moral decorrente de sua violação; [...]

Art. $6^{\circ}$ São direitos sociais a educação, a saúde, a alimentação, o trabalho, a moradia, o transporte, o lazer, a segurança, a previdência social, a proteção à maternidade e à infância, a assistência aos desamparados, na forma desta Constituição.

107 SOUZA, Robert Augusto de; SCHIRMER, Julia Barros; ANNONI, Danielle. O desmantelamento do ser LGBTI: invisibilidade e desumanização do eu frente à problemática dos refugiados no panorama brasileiro. In: ANNONI, Danielle (Coord.). Direito Internacional dos Refugiados e o Brasil. Curitiba: Gedai/UFPR, 2018, p. 453. 
sexual. A ONU promove campanhas para incentivar a aceitação e inclusão desse grupo na sociedade, mas esta ainda se mostra conservadora e preconceituosa - ou é um problema que a sociedade brasileira não está disposta a enfrentar pela homofobia ainda presente em parte da sociedade ${ }^{108}$.

Diante disso, dentro da nossa sociedade sexista e patriarcal, a comunidade LGBTI é vítima de supressão e domínio, sendo a única alternativa ter resistência contra as agressões físicas e psicológicas. Essa supressão acarreta no fenômeno conhecido como invisibilidade, pois é continuamente imposto a essa minoria, através da violência, uma postura ideal de um controle social. O refugiado, em razão da sua fragilidade e para resguardar a própria vida, estará disposto a cumprir as exigências, evidenciando a marginalização da própria personalidade ${ }^{109}$.

É sabido que 76 países ainda criminalizam a união entre pessoas no mesmo sexo, sendo 35 deles países africanos e 26 asiáticos. Vale ressaltar que no Iraque, Irão, Mauritânia, Arábia Saudita, Sudão, Iémen, Nigéria e Somália, a pena para a união entre pessoas do mesmo sexo é a pena de morte. Para essas pessoas há uma homofobia de ordem familiar, política, jurídica, religiosa e estatal legitimada, fato que justifica o fundado temor de perseguição, em virtude da sua orientação sexual ou identidade de gênero. E, ainda que a homofobia não seja institucionalizada, ela continua intrínseca na sociedade civil, como é o caso da Rússia, por exemplo ${ }^{110}$.

A cada 113 pessoas do planeta, uma é solicitante de refúgio, deslocada interna ou refugiada ${ }^{111}$. O Brasil integra o Programa de Reassentamento

\footnotetext{
108 Ibid., p. 455.

109 Ibid., p. 456.

110 ANDRADE, Vitor Lopes. Refugiados e refugiadas por orientação sexual no Brasil: dimensões jurídicas e sociais. In: Seminário “Migrações Internacionais, Refúgio e Políticas”. São Paulo, 2016, p. 5 .

111 BERTOTTI, Bárbara Mariana de Mendonça A.; CASAGRANDE, Melissa Martins. Direitos econômicos, sociais e culturais dos refugiados Brasil: uma análise à luz da dignidade humana. In:
} 
Voluntário das Nações Unidas e recebe muitos refugiados da América do Sul. É preciso preservar e defender os costumes e cultura dessas pessoas em um espaço democrático para que a assimilação delas com a nova realidade seja mais digna ${ }^{112}$.

Noutro giro, tendo em vista que a orientação sexual e a identidade de gênero são aspectos muito íntimos da personalidade da pessoa, se o indivíduo tiver outro motivo cabível para a solicitação de refúgio, geralmente será mencionado em vez da sexualidade. Por exemplo, um nigeriano gay, proveniente de onde há conflito terrorista, provavelmente pedirá refúgio em razão do temor ao Boko Haram ${ }^{113}$, em vez de relatar a perseguição referente à sua orientação sexual. Assim como os sírios, nacionalidade que, de acordo com a Resolução Normativa 17/2018 (CONARE) ${ }^{114}$, possui um processo de solicitação de visto facilitado, o Visto Humanitário, conseguem entrar mais facilmente no Brasil e não precisam comentar a sua orientação sexual, que é fonte de discriminação, perseguição e violência. Isto posto, não necessariamente os índices quantitativos de pessoas homossexuais solicitando refúgio é o que condiz com a realidade ${ }^{115}$.

E, ainda, há receio de sofrerem preconceito por parte das outras pessoas refugiadas que são da mesma nacionalidade que o recém-solicitante:

A gente já teve um caso no final do ano passado (2013), início desse ano, de um refugiado que estava fugindo por isso (ser homossexual) e aí a gente precisou da ajuda de um tradutor, uma

ANNONI, Danielle (Coord.). Direito Internacional dos Refugiados e o Brasil. Curitiba: Gedai/UFPR, 2018, p. 368.

${ }^{112}$ Ibid., p. 369.

${ }^{113}$ Organização fundamentalista islâmica de métodos terroristas.

114 CONARE. Resolução Normativa CONARE $n^{o} 17$ de 20/09/2013. Disponível em: <https://www.conjur.com.br/dl/resolucao-siria-refugiados.pdf>. Acesso em 8 out. 2018.

115 ANDRADE, Vitor Lopes. Refugiados e refugiadas por orientação sexual no Brasil: dimensões jurídicas e sociais. In: Seminário "Migrações Internacionais, Refúgio e Políticas", São Paulo, 2016, p. 7-8. 
pessoa do país dele, e quando ele começou a relatar, o africano, o refugiado que tava acompanhando, olhou e disse: "ah, ele é tá pedindo refúgio porque ele é "viado"'. E ele começou a falar... A gente não entendia o que ele tava dizendo, mas percebeu que ali rolou um conflito, porque a pessoa descobriu que ele era (homossexual). A gente tá tentando aprender a lidar com esses $\operatorname{casos}^{116}$.

Além do viés familiar, no Brasil, é difícil realizar mobilização política, social e administrativa. Há relatos de refugiados que, quando chegaram aqui, foram induzidos a irem para igrejas "curarem" a sua homossexualidade, como se fosse consequência do trauma que viveram, ou da repressão sexual que havia em seu país. Mas as Cáritas continuam sendo o principal local de acolhimento para os refugiados e, até 2016, em São Paulo, foram recebidas aproximadamente 200 pessoas LGBT $^{117}$.

Entretanto, não há um padrão de entrevistas das autoridades e responsáveis para receberem essas pessoas sem estar em uma zona cinzenta e desconfortável por adentrar na intimidade do indivíduo. O entrevistador, em tese, deveria se ater à narrativa do solicitante com senso crítico, ou seja, percebendo se as histórias são mais ou menos críveis, se condizem com a realidade cotidiana de outros relatos, se a ordem cronológica e o discurso são coerentes, entre outras questões relevantes. Contudo, nas zonas de fronteiras, a Polícia Federal mostrou-se indelicada nos processos administrativos internos, enfatizando o seu despreparo frente à situação. Da mesma forma, o CONARE, ao longo dos anos, por exemplo, questionava se a pessoa era a "ativa" ou a "passiva" nas relações sexuais. Evidentemente, a narrativa do solicitante deve

\footnotetext{
116 Esse relato foi dado ao Vitor Lopes de Andrade durante a Feira Nacional de Práticas de Enfrentamento ao Tráfico de Pessoas e Experiências de Políticas Migratórias e Refúgio, em São Paulo, 31 de maio de 2014.20 Disponível <http://www.nepo.unicamp.br/publicacoes/anais/arquivos/22_VLA.pdf>, p. 8. Acesso em 8 out. 2018. 117 FRANÇA, Isadora Lins. "Refugiados LGBTI": direitos e narrativas entrecruzando gênero, sexualidade e violência. In: Cadernos Pagu [online]. Dossiê Conservadorismo, Direitos, Moralidades e Violência, São Paulo, n. ${ }^{\circ}$ 50, 2017, p. 13-14.
} 
ser plausível e passar credibilidade para o entrevistador, mas este deve ter sensibilidade e preparo para a sua análise, ainda que necessite de evidências, documentos e informações do outro país, deve preservar a intimidade do solicitante. Sobre outra ótica, a Polícia Federal e o CONARE precisam conter as fraudes nos pedidos de refúgio para não fragilizarem esse instituto importante para a proteção dos direitos humanos ${ }^{118}$.

O preconceito pode levar alguns a acreditar que o abuso a esses indivíduos não é perseguição, ou a tratar pessoas LGBTI com desrespeito. A veracidade dos depoimentos de uma pessoa às vezes é avaliada com base em suposições estereotipadas, e alguns solicitantes de refúgio são até mesmo obrigados a "provar" sua orientação sexual ou identidade de gênero sexual por meios inadequados (como a exigência de prova de atos íntimos ou teste de resposta a imagens explícitas), que podem, por si só, constituir uma violação de direitos humanos ${ }^{119}$.

Mas, ainda que não se negue a recepção desses refugiados, o Brasil ainda é deficiente no amparo quando não se enquadra no padrão sexual da nossa sociedade e, mesmo que o Brasil ainda tente proteger o direito dessas pessoas, ainda é pouco concreto e o país é omisso em algumas situações, refém do seu conservadorismo ${ }^{120}$.

De acordo com a Cartilha Informativa sobre a Proteção de Pessoas Refugiadas e Solicitantes de Refúgio LGBTI, do ACNUR (2017), o processo

\footnotetext{
118 FRANÇA, Isadora Lins. "Refugiados LGBTI": direitos e narrativas entrecruzando gênero, sexualidade e violência. In: Cadernos Pagu [online]. Dossiê Conservadorismo, Direitos, Moralidades e Violência, São Paulo, n. ${ }^{\circ}$ 50, 2017, p. 15, 17-19.

${ }_{119}$ ACNUR. Cartilha Informativa sobre a Proteção de Pessoas Refugiadas e Solicitantes de Refúgio LGBTI. Disponível em: <http://www.acnur.org/portugues/wp-content/uploads/2018/02/Cartilhainformativa-sobre-a-prote $\% \mathrm{C} 3 \% \mathrm{~A} 7 \% \mathrm{C} 3 \% \mathrm{~A} 3 \mathrm{o}$-de-pessoas-refugiadas-e-solicitantes-deref\%C3\%BAgio-LGBTI_ACNUR-2017.pdf>. Acesso em 6 out. 2018.

${ }^{120}$ SOUZA, Robert Augusto de; SCHIRMER, Julia Barros; ANNONI, Danielle. O desmantelamento do ser LGBTI: invisibilidade e desumanização do eu frente à problemática dos refugiados no panorama brasileiro. In: ANNONI, Danielle (Coord.). Direito Internacional dos Refugiados e o Brasil. Curitiba: Gedai/UFPR, 2018, p. 458.
} 
de solicitação de refúgio deve ser empregado através de métodos respeitosos de comunicação e técnicas sensíveis de entrevistas pelos agentes de migração e oficias de elegibilidade; deve ser garantida a segurança de solicitantes de refúgio LGBTI, bem como daqueles que alegam perseguição com base em orientação sexual ou identidade de gênero socialmente percebidas; é proibido qualquer violação à confidencialidade, imparcialidade e ao respeito universal; é proibido qualquer "teste" de orientação sexual ou identidade de gênero que viole os direitos humanos; é importante permitir que pessoas LGBTI vivam e permaneçam com os seus entes queridos, incluindo parceiros e filhos.

\subsection{PRINCÍPIOS PERTINENTES}

Depois do episódio alemão contra os judeus, comunistas, homossexuais, ciganos, pessoas com deficiência e outras minorias, os Estados criaram a ONU em prol de uma paz mundial ${ }^{121}$. Os homossexuais foram as principais vítimas de castração nessa época, pois eram acusados de ameaçar a evolução da Alemanha. Também por isso, os direitos humanos visam proteger as pessoas de ações que interfiram sua liberdade ou violem sua dignidade humana ${ }^{122}$.

Após o julgamento do caso Toonen v. Austrália, no qual ficou evidenciado que as leis da Austrália violavam direitos humanos LGBTI, o Comitê Internacional de Direitos Humanos estabeleceu que as leis que violem os diretos LGBTI violam também os direitos humanos ${ }^{123}$. O Brasil e a África do Sul, em 2011, foram os primeiros a apresentarem uma Resolução no

${ }^{121}$ GORISCH, 2014, n. p., apud SIQUEIRA; MACHADO, 2018, p. 171.

${ }^{122}$ SIQUEIRA, Dirceu Pereira; MACHADO, Robson Aparecido. A proteção dos direitos humanos LGBT e os princípios consagrados contra a discriminação atentatória. In: Revista Direitos Humanos e democracia. Rio Grande do Sul: Editora Unijui, ano 6, n. ${ }^{\circ} 11,2018$, p. 172-173.

123 GORISCH, Patrícia. O reconhecimento dos direitos humanos LGBT: de Stonewall à ONU. Curitiba: Appris, 2014, p. 41. 
Conselho de Direitos Humanos da ONU, chamada de "Direitos Humanos, orientação sexual e identidade de gênero", para ser aprovada pela ONU.

A Constituição Federal de 1988 possui quatro objetivos importantes: promover o bem de todos, sem preconceitos de origem, raça, sexo, cor, idade e quaisquer outras formas de discriminação $\left(\operatorname{artigo~} 3^{\circ}\right.$ ); promover a dignidade da pessoa humana, com repúdio à discriminação e preconceito, através da promoção da igualdade, podendo ter políticas públicas para combate à discriminação, aumentando a participação das minorias no processo político, acesso à educação, emprego, e assim, corrigindo a desigualdade (art. $1^{\circ}$, inciso III), sendo que a lei punirá qualquer discriminação atentatória aos direitos e liberdades fundamentais (art. $5^{\circ}$, inciso XLI) ${ }^{124}$.

Não é possível que um Estado não promova o bem de todos e colabore para a vida digna da sua sociedade. Muitos países ainda não conseguem a efetiva garantia dos direitos LGBTI e a discriminação continua violando direitos da personalidade, tais como o da honra, da vida privada e da liberdade ${ }^{125}$.

O artigo $5^{\circ}$, inciso XLI, da Constituição Federal de 1988, é claro no sentido de que a lei punirá formas de discriminação que atentem contra a liberdade, realizando, assim, a vedação da discriminação como um direito fundamental. Por outro lado, a heterossexualidade, a institucionalidade e a realidade social se mostram em outro caminho:

[...] a realidade social tem cunho cultural, até mesmo político, e se revela em razão da heteronormatividade vigente, de forma que as pessoas até toleram ou simpatizam com os homossexuais, todavia

${ }^{124}$ SIQUEIRA, Dirceu Pereira; MACHADO, Robson Aparecido. A proteção dos direitos humanos LGBT e os princípios consagrados contra a discriminação atentatória. In: Revista Direitos Humanos e democracia. Rio Grande do Sul: Editora Unijui, ano 6, n. ${ }^{\circ}$ 11, 2018, p. 170.

${ }^{125}$ Ibid., p. 179. 
não aceitam políticas públicas de igualdade para essa classe estigmatizada. É a chamada de homofobia cognitiva, isto é, 'ninguém rejeita os homossexuais, entretanto, ninguém fica chocado pelo fato de que eles não usufruam dos mesmos direitos reconhecidos aos heterossexuais' ${ }^{126}$.

Já o princípio da dignidade da pessoa humana preza o livre desenvolvimento do indivíduo e, por isso, o legislador deveria criminalizar qualquer tipo de violação a esse princípio, uma vez que é núcleo dos direitos fundamentais. Assim como a igualdade formal, reconhecendo todos perante a lei, independente da sua orientação sexual. Deve-se prezar pelo direito à diferença, sem que apenas o heterossexual seja o sujeito de direito e que não haja um reconhecimento da dignidade dos sujeitos distintos. Por isso, deve haver políticas públicas para combater a discriminação e corrigir a desigualdade $^{127}$, ainda que a violência e discriminação homofóbica sejam crescentes no Brasil, deve-se garantir o direito à liberdade dessa minoria se manifestar e lutar pelos seus direitos, para que os mesmos sejam preservados e garantidos efetivamente, já que mostram precisar de uma maior proteção estatal $^{128}$.

Vale mencionar que os direitos da personalidade são direitos ligados à individualidade, liberdade e dignidade. "O direito da personalidade é um direito subjetivo, de caráter não patrimonial, que visa, na verdade, tutelar a própria pessoa humana, a sua dignidade e integridade" ${ }^{29}$.

Mostra-nos Luiz Alberto David Araújo ${ }^{130}$ :

\footnotetext{
${ }^{126}$ BORRILLO, 2015, p. 24, apud. SIQUEIRA; MACHADO, 2018, p. 111-112.

127 SIQUEIRA, Dirceu Pereira; MACHADO, Robson Aparecido. A proteção dos direitos humanos LGBT e os princípios consagrados contra a discriminação atentatória. In: Revista Direitos Humanos e democracia. Rio Grande do Sul: Editora Unijui, ano 6, n. ${ }^{\circ} 11,2018$, p. 180-182, 188.

${ }^{128}$ Ibid., p. 196-197.

${ }^{129}$ CARDIN; BENVENUTO, 2013, p. 121, apud SIQUEIRA; MACHADO, 2018, p. 177.

${ }^{130}$ ARAUJO, Luiz Alberto David. A proteção constitucional do transexual. São Paulo: Saraiva, 2000, p. 74.
} 
[...] ao arrolar princípios como o do Estado democrático, o da dignidade da pessoa humana e o da necessidade da promoção do bem de todos, sem qualquer preconceito, o constituinte garantiu o direito à felicidade. Não o escreveu de forma expressa, mas deixou claro que o Estado, dentro do sistema nacional, tem a função de promover a felicidade, pois a dignidade, o bem de todos, pressupõe o direito de ser feliz.

Nesse sentido, quando o Brasil é parte de um tratado ou convenção, deve haver aceitação tácita do Estado brasileiro, consoante ao artigo 4, inciso II da Constituição Federal ${ }^{131-132}$.

Também no artigo $5^{\circ}, \S 2^{\circ}$, a Constituição determina que os direitos e garantias nela expressos não excluirão outros advindos de tratados internacionais de que o Brasil seja parte; ainda no $\$ 3^{\circ}$, acrescenta que os tratados e convenções internacionais sobre direitos humanos aprovados em cada casa do Congresso Nacional, em votação de dois turnos, por três quintos dos votos, terão status de norma constitucional equivalente ${ }^{133}$. Os tratados de direitos humanos que não receberem a aprovação do Congresso Nacional, mas forem ratificados e internalizados ao ordenamento jurídico, terão status de norma supralegal, ou seja, abaixo da Constituição Federal e acima das leis ordinárias ${ }^{134}$.

Também devemos ter em vista o princípio da unidade familiar dos refugiados, o qual revela a importância família, tal como um ambiente de afeto e solidariedade, principalmente nesse momento tão delicado, para o desenvolvimento saudável e não exposição ainda maior na sua vulnerabilidade,

${ }^{131}$ SIQUEIRA, Dirceu Pereira; MACHADO, Robson Aparecido. A proteção dos direitos humanos LGBT e os princípios consagrados contra a discriminação atentatória. In: Revista Direitos Humanos e democracia. Rio Grande do Sul: Editora Unijui, ano 6, n. ${ }^{\circ} 11,2018$, p. 178.

132 Art. $4^{\circ}$ : A República Federativa do Brasil rege-se nas suas relações internacionais pelos seguintes princípios: II - prevalência dos direitos humanos.

${ }^{133}$ SIQUEIRA, Dirceu Pereira; MACHADO, Robson Aparecido. Op. Cit., p. 175.

${ }^{134}$ Ibid., p. 175 
garantindo a dignidade e integração local no novo país, esse espaço de realização pessoal e afetiva com os seus familiares ${ }^{135}$. Mas nem sempre foi assim:

Inicialmente, as relações de família eram tratadas meramente como relações patrimoniais. A família desempenhava funções econômicas, políticas, religiosas e procracional, isto é, era constituída unicamente com o fim de gerar descendentes, porque a religião assim determinava e seus membros eram importantes, pois serviam como unidade produtiva para o sustento da família e seguro contra a velhice ${ }^{136}$.

A família tradicional, patriarcal e desigual entre homens e mulheres foi perdendo espaço, muito em detrimento da progressiva emancipação da mulher escolhendo os próprios caminhos, inovações sociais e a redução do número de filhos nas famílias: "A antiga família patriarcal é substituída pela família baseada em valores de solidariedade, respeito, coordenação e comunhão de interesses de vida" 137 .

Contudo, a natureza patriarcal não desaparece, apenas perde força, como uma forma suplementar, a família moderna possui fundamento na valorização do ser, afetividade e preocupação com os interesses da pessoa humana ${ }^{138}$. Conforme aponta Dias ${ }^{139}$ : “o que caracteriza a família no mundo moderno é a presença do vínculo afetivo a unir as pessoas com identidade de projetos de vida e propósitos comuns, gerando comprometimento mútuo".

\footnotetext{
${ }^{135}$ SOARES, Carina de Oliveira. Análise do princípio da unidade familiar no direito internacional dos refugiados. In: Revista Universitas Relações Internacionais. Brasília, v. 10, n. ${ }^{\circ}$ 1, jan./jun., 2012, p. 121-122.

${ }^{136}$ LÔBO, 2004, n. p., apud SOARES, 2012, p. 124-125.

${ }^{137}$ LÔBO, 2004, n. p., apud SOARES, 2012, p. 125.

${ }^{138}$ SOARES, Carina de Oliveira. Op. Cit., p. 125.

${ }^{139}$ DIAS, 2007, n. p., apud SOARES, 2012, p. 127.
} 
A Convenção de 1951 consagrou a proteção à família do refugiado, com garantia à manutenção da unidade familiar, mesmo que os outros membros da família não preencham os pré-requisitos para serem considerados também como tal. Essa medida é para facilitar a integração do refugiado no novo ambiente, aproximando o que já é conhecido para superar os obstáculos do que aconteceu e para construírem um futuro melhor, assim como tenta garantir uma vida digna e feliz para aqueles que já sofreram graves violações de direitos humanos. Portanto, deve-se garantir um espaço de proteção mais amplo para os refugiados e os seus familiares ${ }^{140}$.

Tal Convenção de 1951 também recomendou que os governos adotassem medidas para a proteção das famílias do refugiado para que a unidade familiar fosse mantida, com os respectivos meios para a sua manutenção. A Declaração Universal dos Direitos do Homem declara que "família é a unidade de grupo natural e fundamental da sociedade e tem direito a ser protegida pelo Estado".

Da mesma forma, em 2009, o ACNUR recomendou que os Estados se esforçassem para a proteção família e para que ela permaneça unida. A Convenção de 1951 não introduz explicitamente o princípio da unidade familiar, apenas realiza recomendações, o que é observado pela maioria dos Estados $^{141}$.

O princípio da unidade familiar determina que a família permaneça unida e que não seja separada por razões alheias a sua vontade. Está estreitamente ligado ao princípio da dignidade da pessoa humana, princípio da igualdade, afetividade e convivência familiar.

\footnotetext{
${ }^{140}$ SOARES, Carina de Oliveira. Op. Cit., p. 124.

${ }^{141}$ Ibid., p. 133.
} 
É evidente que o panorama dos refugiados está ligado aos direitos da pessoa humana, uma vez que são forçados a abandonar os seus lares para fugirem da perseguição e de uma série de violações de direitos humanos, violações do direito à vida e à vida familiar, à liberdade, à privacidade, à liberdade de locomoção e residência, à segurança e ao direito a não ser submetido à tortura e ao exílio arbitrário, devendo o Estado que o recebe, atendê-lo e protegê-lo com dignidade ${ }^{142}$.

Diante disso, tem-se o reconhecimento das inúmeras entidades familiares existentes na sociedade e não apenas a família clássica formada pelo casamento, mas também as formadas com companheiros, ou seja, oriundas da união estável, seja ela homoafetiva ou não, as quais devem receber proteção da unidade familiar.

O CONARE é responsável por implementar políticas públicas com orientação e coordenação de ações para a eficácia da proteção da família, assistência e apoio jurídico, em virtude do art. $2^{\circ}$ da lei 9.474/1997, no qual há a possibilidade do refugiado reunir-se com o seu grupo familiar quando encontrarem-se em território nacional, enquanto perdurar a necessidade de proteção. No Brasil, o CONARE possui a Resolução Normativa nº 4, de 1998, que ratifica a extensão da condição de refugiado a título de reunião familiar, conforme a recomendação da Convenção de 1951, levando em conta o pluralismo das entidades familiares, ou seja, não só o cônjuge receberá a proteção da unidade familiar, mas também o companheiro ${ }^{143}$.

A proteção da família, portanto, é indispensável nesse processo, devendo ser respaldada pela intervenção do Estado, uma vez que deve fornecer melhores condições de vida ${ }^{144}$.

\footnotetext{
${ }^{142}$ Ibid., p. 132.

${ }^{143}$ Ibid., p. 134-135.

${ }^{144}$ Ibid., p. 135.
} 


\subsection{A TEMÁTICA DA FAMÍLIA}

Como já abordado, as pessoas que buscam refúgio em razão da sua orientação sexual ou identidade de gênero, são vítimas de discriminação, violência sexual física e psicológica, abuso sexual, falta de proteção policial, estupros corretivos, exclusão social e familiar. Por não pertencerem à heteronormatividade, suas vidas tornam-se insuportáveis e perigosas. Já se afirmou ainda que o ACNUR reconhece o refúgio pela proteção a um grupo social e que muitos pedem refúgio sem declararem o verdadeiro motivo para migrarem, pois não conhecem a realidade brasileira sobre discriminação ${ }^{145}$.

Os refugiados sírios, por exemplo, não fogem apenas do governo de Assad, mas também fogem do Estado Islâmico e geralmente se direcionam para a Turquia e para a Grécia. Nesses dois países, passam por entrevistas de fronteiras e são abordados de forma insensível e inapropriada, sofrendo intolerância, violência, discriminação, além das práticas sexuais ditas como corretivas. Não há despreparo apenas no Brasil: a Inglaterra, a Alemanha e o Canadá, ainda são protagonistas de casos em que oficiais de fronteira praticam violência psicológica e estupros corretivos ${ }^{146}$.

A maioria dos refugiados por orientação sexual e identidade de gênero é oriunda de países que não reconhecem legalmente casais e famílias homoafetivas, fomentam o preconceito e possuem pena de morte como consequência para tal união - apesar do parágrafo 69 do Relatório da Agência

\footnotetext{
145 GORISCH, Patrícia Cristina Vasques de Souza. A família LGBTI na perspectiva do direito internacional dos refugiados. In: Revista do Direito. Santa Cruz do Sul, v. 3, n. ${ }^{\circ}$ 50, set./dez., 2016, p. 72.

${ }^{146}$ Ibid., p. 73.
} 
da ONU para Refugiados tratar essa prática como discriminatória contra os indivíduos LGBTI ${ }^{147}$.

Sußner (2013) cita um caso onde um solicitante Afegão matinha um relacionamento homoafetivo a mais de 6 meses, quando foi descoberto e atacado por um grupo de homens de sua vila. Nesse ataque, seu parceiro foi morto. Ao deixar o país, seu pedido de refúgio foi concedido na Áustria. Segundo o autor, conforme o estudo que fez da legislação austríaca, caso o parceiro do solicitante tivesse sobrevivido e solicitado a união familiar após o reconhecimento do refúgio do solicitante, este precisaria comprovar a união com o registro da mesma. Na lei Afegã, tal registro é inexistente (Sußner, 2013, p.180) e a ameaça de morte é uma realidade para indivíduos e casais homoafetivos ${ }^{148}$.

Nessa perspectiva, a visibilidade é fundamental para o pedido de reunificação ${ }^{149}$. Essas pessoas, em países como o Afeganistão, mantêm uma relação discreta, tendo uma invisibilidade familiar, o que dificulta a reunificação familiar LGBTI, pois não há evidências como fotos, documentos, respaldo legal, conhecimento de familiares, por exemplo. Então, mesmo que um casal homoafetivo possua uma união estável, comprovar essa vida familiar é muito difícil, não existindo nem o aspecto de círculo social da mesma e sem prova do vínculo, pois a discrição é fundamental para a segurança, tornando a possibilidade de reunificação familiar remota ${ }^{150}$. Sem a documentação que prova a existência da união, os companheiros são separados a partir do momento em que cruzam a fronteira, ficando cada um em um país diferente ${ }^{151}$.

Mesmo assim, quando as pessoas alegarem que existe uma união de fato, o Estado receptor deve facilitar a entrada, residência e manutenção de

\footnotetext{
${ }^{147}$ Ibid., p. 74.

${ }^{148}$ Ibid., p. 75.

${ }^{149}$ Ibid., p. 75.

${ }^{150}$ Ibid., p. 76.

${ }^{151}$ Ibid., p. 77.
} 
ambos no mesmo ambiente, em virtude do princípio da unidade familiar fundamental nesse processo, como já visto no capítulo anterior.

A reunificação das famílias possui seu prisma nos direitos fundamentais, caracterizado pela vida privada e princípio da não discriminação. Os refugiados devem comprovar que recebem salário suficiente para pagar pelos seus gastos e o da sua família quando realizam o pedido de reunificação familiar. Em alguns países, esse pedido só pode ser feito até três meses depois do ingresso do refugiado no Brasil, o que não é prudente, pois em algumas situações de guerra e violência generalizada, pode demorar mais de três meses para o indivíduo encontrar os membros da família e ainda ter de separar todos os documentos necessários de forma correta para apresentação, devendo superar a burocracia. Esse processo pode durar até sete anos, de acordo com a Cruz Vermelha, pois muitos documentos se perdem no momento da fuga ${ }^{152}$.

Todavia, é necessário priorizar o processo de reunificação familiar, sendo ele o caminho necessário para estabelecer uma vida em família possível, com desenvolvimento saudável no novo país, para integração local e social, criando estabilidade sociocultural, pois a família é o verdadeiro alicerce dessas pessoas, em consonância com os direitos fundamentais ${ }^{153}$.

\footnotetext{
152 Ibid., p. 78.
}

${ }^{153}$ Ibid., p. 79. 


\section{A ATUAÇÃO DA CRUZ VERMELHA NA REUNIFICAÇÃO FAMILIAR}

No dia 08 de novembro de 2018, foi realizada uma reunião na Cruz Vermelha Brasil, no Rio de Janeiro, para conversar com as coordenadoras de Restabelecimento de Laços Familiares (RLF) e Migração e Refúgio. Observase que a Cruz Vermelha é uma organização neutra e não se posiciona politicamente. Além disso, não pode fornecer dados mais aprofundados sobre os casos, mantendo-os em sigilo para a segurança e sucesso das suas mediações e atendimentos.

A coordenadora do Restabelecimento de Laços Familiares, Tayna Rodrigues, explicou que o RLF é criado para reestabelecer e manter o contato dos refugiados com a sua família. Eles possuem alguns critérios de cunho humanitário. Se as famílias se separaram por questões climáticas, por exemplo, ou desastres, emergências, conflitos (guerras, conflitos armados, condições de violência), ou por migração internacional. Esse último, atualmente, é o que possui maior intensidade de casos, em virtude do aumento do fluxo de imigrantes.

Então, no RLF, o maior desafio enfrentado é a busca por pessoas, para poder reestabelecer o contato entre elas e também para manter tal comunicação através de telefone ou mensagem, a fim de aproximá-las. Normalmente, no Brasil, para as pessoas que estão buscando familiares em outros países, eles também fazem o trabalho de buscar o familiar no país procurado, ou até mesmo dentro do próprio território nacional, dependendo das informações que

obtiverem. Como exemplo de tal situação, tem-se o caso, ocorrido em 2015, de um casal homoafetivo senegalês, que saiu de Senegal por questões de 
orientação sexual. Durante a migração, um deles dirigiu-se para um determinado país e o outro veio para o Brasil.

A coordenadora não soube informar, até o determinado momento, se o casal conseguiu tirar alguma documentação para comprovar sua unidade familiar ou para estabelecê-la legalmente. Também relatou que ainda não se conseguiu encontrar a outra pessoa, que pode estar ainda em outro país, ou no Brasil - visto que tal indivíduo pode já ter saído de onde estava inicialmente. Quando se trata de refúgio é normal existir a presença de coiotes; às vezes a pessoa afirma ir para um lugar, apenas para despistar, já que, na verdade, vai para outro. Como eles saem do país por perseguição, é um pouco mais complicado encontrá-los.

Foi aberto, em Manaus, um novo abrigo para LGBTs, com o fim de acolher, principalmente, os imigrantes venezuelanos. Há também o abrigo do Rio de Janeiro, no bairro do Recreio, que recebeu, em seu processo de interiorização ${ }^{154}$, alguns venezuelanos e também pessoas LGBTs. O Rio de Janeiro já adquiriu interiorização de três abrigos da Igreja Católica, porém apenas a paróquia no Recreio recebe LGBTs. Os outros dois abrigos cariocas são mistos e destinados para famílias.

A coordenadora se posicionou no sentido de que o país possui uma lei ideal no seu ordenamento (Lei $\mathrm{n}^{\circ}$ 9.474/1997) que, em teoria, acolheria as pessoas de uma forma digna. No entanto, ainda existem dificuldades relativas à xenofobia, ao preconceito, ao racismo, à falta de acesso à língua e a dificuldades culturais, e que, infelizmente, os refugiados que aqui chegam

\footnotetext{
154 Trabalham, atualmente, principalmente em Roraima, a "interiorização". Interiorização é um programa do Governo Federal com a ONU e a ACNUR, que se juntaram para tirar as pessoas de Roraima, em razão do interno fluxo migratório, já que a cidade de Boa Vista e o Estado de Roraima não possuem capacidade para receber muita gente, pois possuem condições precárias. Então, tais órgãos deslocaram essas pessoas para outras regiões do país com os aviões da Força Aérea Brasileira (FAB), com um ou dois voos por semana, que possuíam capacidade para 200 ou 100 pessoas, e, até agora, foram aproximadamente 3.000 pessoas interiorizadas.
} 
podem não ter os seus direitos exercidos plenamente. Não há um documento padrão estadual, regional ou nacional; em muitos casos, somente é fornecida uma numeração e dados básicos em uma folha de papel. O maior receio deles é serem abordados por policiais e terem de entregar um papel de celeridade mínima, além de não saberem a reação dos policiais, se são treinados e conhecem esse tipo de identificação. Nota-se, dessa forma, que, se a pessoa não souber se comunicar, ou se está em um período de recém-chegada, há um impedimento e uma complexidade ainda maior nesse processo.

Os refugiados relatam que não são muito bem atendidos pelos agentes responsáveis ao chegarem ao país e ao pegarem identificações. O documento que recebem é em português e o refugiado, geralmente, não conhece o idioma para ler e se identificar. A coordenadora sobre Migração e Refúgio salientou que, apenas recentemente, a Polícia Federal tornou a ter um grupo treinado para receber essas pessoas. E que a Polícia Federal está acostumada e treinada para receber traficantes, pessoas procuradas pela INTERPOL ${ }^{155}$, e não para receber refugiados. Então, a abordagem tem de ser diferente, e agora, para isso, a Polícia Federal está aprendendo a lidar com o público dessa nova demanda tais agentes não são exatamente agressivos e preconceituosos; na verdade, o atendimento está mais relacionado ao treinamento que recebem.

O departamento de Migração e Refúgio é um departamento novo na Cruz Vermelha, que foi criado para receber migrantes e refugiados. Eles preenchem uma ficha e o departamento identifica suas necessidades de assistência social, cesta básica, psicólogos e Restabelecimento de Laços Familiares. Como não dispõem de um departamento jurídico, possuem uma parceria com a Casa Ruy Barbosa e, se necessário, realizam o encaminhamento de tais indivíduos a essa localidade, acompanhando-os até lá, ou até à Polícia Federal, ou onde houver necessidade, sempre com a assistência do setor jurídico da Casa Ruy Barbosa.

\footnotetext{
155 Organização Internacional de Polícia Criminal.
} 
$\mathrm{Na}$ maioria das vezes, os solicitantes desejam traduzir um documento, ou buscam alimentação e fazer currículo. Contudo, o maior obstáculo para a Cruz Vermelha é a língua. Lá havia um curso destinado a essas pessoas que está suspenso, porém estão trabalhando para retomá-lo, pois o idioma é fundamental para elas se comunicarem no dia a dia, para construírem círculos sociais e conseguirem um trabalho.

A coordenadora do RLF ressaltou que é importante o reestabelecimento dos laços familiares, principalmente, por estarem em um lugar que não conhecem ninguém, por isso, eles precisam de um ponto de referência, ainda que estejam fisicamente longe dos familiares. Muitos dos venezuelanos, por exemplo, têm de vender o telefone celular para conseguir dinheiro, no entanto também são roubados, fato que dificulta a comunicação com a família. Portanto, quando eles conseguem falar com algum familiar é emocionante.

Tais refugiados usam o Brasil como uma transição para outro lugar. Há três meses, o Brasil tinha 120.000 (cento e vinte mil) venezuelanos que tinham passado por aqui, mas só 40.000 (quarenta mil) tinham se fixado, os outros 80.000 (oitenta mil) não ficaram. Quando a pessoa chega porque está fugindo de uma guerra ou de um conflito armado é ainda mais delicado, pois, na maioria das vezes, o familiar que ficou também já foi para outro lugar.

O Brasil ainda é carente de políticas públicas que abordem, principalmente pelos agentes de saúde, a questão da diversidade, de compreensão do outro, da situação da pessoa que está na frente dele que não fala aquela língua, que não conhece aquele remédio, que não sabe como manejá-lo - o que também vale para os outros setores. Com esse fluxo intenso de venezuelanos, o Brasil acertou na medida em que não fechou as fronteiras, apesar das críticas e de alguns episódios contrários a essa linha. Além disso, a Operação Acolhida (operação do Exército Brasileiro) que está atuando nessa área funciona bem, 
apesar da fragilidade das pessoas e, por ser pelo Exército, não há uma pressão bélica, as pessoas não se sentem retraídas pela presença deles, ao contrário, a operação possui mais um viés de abrigo, que conseguem construir, rapidamente, alimentação, o que demonstra um aceno positivo. Entretanto, apesar de o Brasil possuir uma lei moderna, a população ainda não consegue abraçar completamente essa questão.

Em São Paulo, existe um bom exemplo de abrigo, já que recebe $60 \%$ dos migrantes no Brasil; nesse sentido, tal estado denota certa experiência na área, uma vez que os migrantes têm abrigos públicos. No Rio de Janeiro, existem algumas casas de passagem: a paróquia do Padre Mário, no bairro de Botafogo; o coletivo de migrações da PUC e a Cáritas; a paróquia Santa Cecília, também em Botafogo, que abriga refugiados temporariamente em situações mais vulneráveis e a paróquia do Padre Alex. Contudo, como já abordado, são abrigos temporários, visto que encaminham tais indivíduos para um lugar com mais estrutura. Ademais, no bairro de Brás de Pina existe uma comunidade congolesa de migrantes e refugiados.

No caso dos venezuelanos, também existem os abrigos privados, que são fruto da parceria do Governo Federal com o ACNUR e recebem apenas os interiorizados. Em Manaus ou em Boa Vista, eles recebem uma documentação e são encaminhados para os abrigos. Os locais podem possuir perfis de pessoas que desejam receber, sendo eles: perfil de homens solteiros, perfil de famílias, e assim por diante. O ACNUR faz uma triagem nos abrigos em Roraima para saber quem deseja ser interiorizado, mas a coordenadora não soube informar se é pela vulnerabilidade, ordem de chegada, ou qualquer outro critério.

O fluxo de migração tende a aumentar e a Cruz Vermelha possui esperança que as leis sejam cumpridas e que o país cada vez mais consiga receber os migrantes da melhor forma possível e com dignidade. 


\section{CONCLUSÃO}

O conceito de quem seria a pessoa refugiada sofreu uma longa evolução. A definição mais ampla e utilizada como referência está disposta na Convenção das Nações Unidas relativa ao Estatuto do Refugiado de 1951, que engloba todos aqueles que, por fundados temores, tenham sido perseguidos por motivos de raça, religião, nacionalidade, por pertencer a determinado grupo social ou por opiniões políticas e, por isso, não consigam proteção do Estado ou que, por temor, não queira regressar ao seu país.

Após a ditadura brasileira, a Declaração de Cartagena (1984) passou a entender como refugiado aqueles que também tenham saído do seu país para preservar a sua vida, segurança ou liberdade, quando as tiveram ameaçadas pela violência generalizada.

A lei brasileira $n^{\circ}$ 9.474/1997 se baseou nessas duas definições para elaborar o Estatuto do Refugiado. O principal direito estabelecido nessa lei, para o presente estudo, está presente no artigo $2^{\circ}$, no qual é previsto o direito à reunião familiar, ou seja, os outros membros da família do refugiado, também terão o refúgio concedido, incluindo o companheiro(a).

Desde 2002, o Brasil concede refúgio motivado pela orientação sexual, seguindo os passos de outros países, pois é visto como um país acolhedor quanto às questões de sexualidade e de gênero. Em 2008, o ACNUR publicou um guia de orientação incluindo a orientação sexual e a identidade de gênero na classificação legal de "grupo social". Dessa forma, a comunidade LGBTI se tornou um grupo social específico para a solicitação de refúgio. 
A partir da Ação Direta de Inconstitucionalidade no 4277 e a Arguição de Descumprimento de Preceito Fundamental no 132, em 2011, o Supremo Tribunal Federal reconheceu a união estável para casais do mesmo sexo, reconhecendo-as como unidade familiar e vedando a interpretação dos dispositivos legais apenas para um determinado grupo da sociedade, tendo em vista os princípios constitucionais de igualdade e de não discriminação.

A Constituição Federal de 1988 estabelece no artigo 226 que a família é a base da sociedade e possui especial proteção do Estado. Então, partindo da premissa que se pode ter uma união estável homoafetiva, a mesma deve ser entendida como uma família e deve possuir proteção especial do Estado. Logo, para esse estudo, essa premissa deve ser analisada em conjunto com os princípios constitucionais da dignidade humana e igualdade, assim como a defesa pela proteção dos direitos sociais, principalmente quando se tratar de pessoas refugiadas.

A família é um ambiente de afeto e solidariedade, em que o refugiado encontra o seu ponto de referência, sua base, uma espécie de porto seguro sólido no qual ele confia. Essa base é fundamental para enfrentar esse momento delicado e para possuir um desenvolvimento saudável na integração local com a garantia de dignidade.

De acordo com a Convenção de 1951, deve haver a manutenção da unidade familiar, mesmo que esses não tenham os pré-requisitos para serem considerados como tal. Contudo, no caso de perseguição por orientação sexual, os dois podem buscar refúgio pela mesma razão, pois ambos são vítimas de discriminação, violência sexual física e psicológica, estupro coletivo, exclusão social e familiar. Nessa lógica, o familiar deve ser utilizado para construírem um futuro tal como uma família. 
No processo de solicitação de refúgio devem ser adotados métodos respeitosos e compatíveis com a realidade sensível do refugiado nas entrevistas realizadas pelos agentes e oficiais competentes, para que a pessoa revele o real sentido do seu refúgio, quais são as suas necessidades e que perspectivas possui em relação ao país ingressante.

É notório que a demanda pode ser considerada atual no Brasil e que, por isso, em alguns processos de solicitação e atendimentos, os procedimentos não tenham sido realizados com a perfeição esperada. Todavia, conforme informado pela Cruz Vermelha Brasileira, os agentes e oficiais responsáveis, em conjunto com o Exército e a sociedade civil - como as Igrejas Católicas, que continuam sendo um apoio - estão trabalhando para atenderem especificamente os refugiados e também os refugiados homoafetivos, uma vez que o princípio da unidade familiar estipula que a família permaneça unida e não seja separada por razões alheias a sua vontade.

Por isso, ao passar pela fronteira, o casal homoafetivo deve ser identificado como tal e, portanto, identificado com família, a fim de permanecer junto, para construir sua vida, possuindo respaldo e proteção da lei brasileira, para não ser separado no cruzamento e ter suas vidas devastadas ainda mais. $\mathrm{O}$ incremento de políticas públicas para informar e educar a população quanto ao novo contingente populacional e a sua realidade, sua diversidade, deve ser encarado com celeridade e comprometimento do Brasil, que ratificou declarações e convenções internacionais importantes e, ainda, possui uma lei considerada internacionalmente como moderna e completa, para que os direitos e os princípios estabelecidos em leis sejam efetivados no cenário nacional. 


\section{REFERÊNCIAS BIBLIOGRÁFICAS}

ACNUR. Cartilha Informativa sobre a Proteção de Pessoas Refugiadas e Solicitantes de Refúgio LGBTI. Disponível em: <http://www.acnur.org/portugues/wp-content/uploads/2018/02/Cartilhainformativa-sobre-a-prote $\% \mathrm{C} 3 \% \mathrm{~A} 7 \% \mathrm{C} 3 \% \mathrm{~A} 3 \mathrm{o}$-de-pessoas-refugiadas-esolicitantes-de-ref\%C3\%BAgio-LGBTI_ACNUR-2017.pdf>. Acesso em 6 out. 2018.

AHLERT, Mara; ALMEIDA, Alcione de. A inclusão social das pessoas na condição de refugiado no Brasil à luz dos direitos humanos. In: Revista Barbarói. Santa Cruz do Sul, Edição Especial n. 47, jan./jun. 2016.

ALTO COMISSARIADO DAS NAÇÕES UNIDAS PARA OS REFUGIADOS. Protegendo os refugiados no Brasil e no Mundo. Brasília: ACNUR, 2014.

ANDRADE, Vitor Lopes. Refugiados e refugiadas por orientação sexual no Brasil: dimensões jurídicas e sociais. In: Seminário "Migrações Internacionais, Refúgio e Políticas”. São Paulo, 2016.

ARAUJO, Luiz Alberto David. A proteção constitucional do transexual. São Paulo: Saraiva, 2000.

BARRETO, Luiz Paulo Teles Ferreira. A Lei Brasileira de Refúgio: sua história. In: BARRETO, Luiz Paulo Teles Ferreira (Org.). Refúgio no Brasil: a proteção brasileira aos refugiados e seu impacto nas Américas. Brasília: ACNUR, Ministério da Justiça, 2010.

BENJÓ, Daniel. Os novos tipos de família: um estudo sobre a união homoafetiva. Rio de Janeiro, 2013. 62 f. Monografia (Monografia em Direito) - Pontifícia Universidade Católica (PUC).

BERTOTTI, Bárbara Mariana de Mendonça A.; CASAGRANDE, Melissa Martins. Direitos econômicos, sociais e culturais dos refugiados Brasil: uma análise à luz da dignidade humana. In: ANNONI, Danielle (Coord.). Direito Internacional dos Refugiados e o Brasil. Curitiba: Gedai/UFPR, 2018.

BRASIL. Código Civil. Lei n. 9.474, de 22 jul. 1997. Define mecanismos para a implementação do Estatuto dos Refugiados de 1951, e determina outras providências. Disponível em: <http://www.planalto.gov.br/ccivil_03/leis/19474.htm>. Acesso em 25 set. 2018. 
Código Civil. Lei n. 10.406, de 10 jan. 2002. Institui o Código Civil. Disponível em: <http://www.planalto.gov.br/ccivil_03/leis/2002/110406.htm>. Acesso em 10 set. 2018.

. Código Civil. Lei n. 13.445, de 24 mai. 2017. Institui a Lei de Migração. Disponível em: <http://www.planalto.gov.br/ccivil_03/_Ato20152018/2017/Lei/L13445.htm>. Acesso em 25 set. 2018.

. Constituição da República Federativa do Brasil de 1988. Art. 226, $\S 3^{\circ}$. Da Família, da Criança, do Adolescente, do Jovem e do Idoso. Disponível em:

$<$ https://www.senado.leg.br/atividade/const/con1988/con1988_04.10.2017/art_ 226_.asp>. Acesso em 10 set. 2018.

CAHALI, Francisco José. Contrato de Convivência na União Estável. São Paulo: Saraiva, 2002.

COMARCA DE PORTO ALEGRE, Apelação Cível n. 70012836755, Rel. Desa. Maria Berenice Dias, Porto Alegre, 21 dez. 2005.

CONARE. Resolução Normativa CONARE $n^{o} 17$ de 20/09/2013. Disponível em: <https://www.conjur.com.br/dl/resolucao-siria-refugiados.pdf>. Acesso em 8 out. 2018.

DIAS, Maria Berenice. Manual de direito das famílias. $12^{\mathrm{a}}$ ed. São Paulo: Editora Revista dos Tribunais, 2017.

União homoafetiva: o preconceito e a justiça. $5^{\mathrm{a}}$ ed. Rio de Janeiro: Editora Revista dos Tribunas, 2012.

FRANÇA, Isadora Lins. "Refugiados LGBTI": direitos e narrativas entrecruzando gênero, sexualidade e violência. In: Cadernos Pagu [online]. Dossiê Conservadorismo, Direitos, Moralidades e Violência, São Paulo, n. ${ }^{\circ}$ 50, 2017.

GONÇALVES, Carlos Roberto. Direito Civil Brasileiro: Direito de Família. Volume 6. 14ª ed. São Paulo: Saraiva, 2017.

GORISCH, Patrícia Cristina Vasques de Souza. A família LGBTI na perspectiva do direito internacional dos refugiados. In: Revista do Direito. Santa Cruz do Sul, v. 3, n. ${ }^{\circ}$ 50, p. 71-80, set./dez., 2016. 
O reconhecimento dos direitos humanos LGBT: de Stonewall à ONU.

Curitiba: Appris, 2014.

LIMA, Marcellus Polastri; TRANCOSO, Renata Vitória Oliveira dos S. União homoafetiva: contornos da decisão em ação declaratória de inconstitucionalidade de conversão do reconhecimento da união homoafetiva em casamento. In: Direito de família [Recurso eletrônico on-line]. Org. CONPEDI/ UNICURITIBA. Coord.: SANTIAGO, Mariana Ribeiro; SILVA, Marcos Alves da; CARDIM, Valéria Silva Galdino. Florianópolis: FUNJAB, 2013.

. União homoafetiva: contornos da decisão em ação declaratória de inconstitucionalidade e as recentes discussões quanto a possibilidade de conversão do reconhecimento da união homoafetiva em casamento. Disponível em: <http://www.publicadireito.com.br/artigos/?cod=9773d3352e206fef $>$. Acesso em 15 set. 2018.

LÔBO, Paulo Luiz Netto. A repersonalização das relações de família. In: Revista Brasileira de Direito de Família. Porto Alegre, n. 24, p. 136-156, jun./jul., 2004.

. Entidades familiares Constitucionalizadas: para além do numerus clausus. In: Revista Brasileira de Direito de Família. Porto Alegre: Síntese, n. 12, p. 40-55, jan./mar. 2002.

MOREIRA, Julia Bertino. Refugiados no Brasil: reflexões acerca do processo de integração local. In: Revista Interdisciplinar da Mobilidade Humana. Brasília, Ano XXII, n. 43, jul./dez. 2014.

PEREIRA, Caio Mário da Silva. Instituições de Direito Civil: Direito de Família. Volume V. 18 a ed. Rio de Janeiro: Editora Forense, 2010.

PORTAL DE NOTÍCIAS DO SUPREMO TRIBUNAL FEDERAL. Supremo reconhece união homoafetiva. <http://www.stf.jus.br/portal/cms/verNoticiaDetalhe.asp?idConteudo=178931> . Acesso em 20 set. 2018.

SIQUEIRA, Dirceu Pereira; MACHADO, Robson Aparecido. A proteção dos direitos humanos LGBT e os princípios consagrados contra a discriminação atentatória. In: Revista Direitos Humanos e democracia. Rio Grande do Sul: Editora Unijui, ano 6, n. ${ }^{\circ}$ 11, 2018. 
SOARES, Carina de Oliveira. Análise do princípio da unidade familiar no direito internacional dos refugiados. In: Revista Universitas Relações Internacionais. Brasília, v. 10, n. ${ }^{\circ}$ 1, p. 123-137, jan./jun., 2012.

SOUZA, Robert Augusto de; SCHIRMER, Julia Barros; ANNONI, Danielle. O desmantelamento do ser LGBTI: invisibilidade e desumanização do eu frente à problemática dos refugiados no panorama brasileiro. In: ANNONI, Danielle (Coord.). Direito Internacional dos Refugiados e o Brasil. Curitiba: Gedai/UFPR, 2018.

STF, ADI n. 4277, Rel. Ministro Ayres Britto, Brasília, 05 mai. 2011.

TJRS, EI n. 70011120573, Rel. José Carlos Teixeira Giorgis, Rio Grande do Sul, 18 nov. 2005.

TSE, Recurso Especial Eleitoral n. 24.564/PA, Rel. Ministro Gilmar Mendes, Brasília, 02 out. 2004.

VARA PREVIDENCIÁRIA DE PORTO ALEGRE, Apelação Cível n. 2000.71.00.009347-0/RS, Rel. Des. Federal João Batista Pinto Silveira, Porto Alegre, 29 jul. 2005.

VIEIRA, Cláudia Nascimento. A união estável no novo código civil. In: EMERJ. Curso 10 anos do código civil: aplicação, acertos, desacertos, e novos rumos. Rio de Janeiro: Divisão de Publicações da EMERJ, 2013.

WIKIPÉDIA. Entidade familiar. Disponível em: <https://pt.wikipedia.org/wiki/Entidade_familiar〉. Acesso em 15 set. 2018. 